\title{
Chapter 4. Posts, Hearths and Thresholds: The Iban Longhouse as a Ritual Structure
}

\section{Clifford Sather}

Social and symbolic features of the Iban longhouse have been extensively described (see Freeman 1960, 1970). These descriptions, however, have consistently given priority to the longhouse as a built form. In this paper I begin by taking a very different approach, viewing the Iban longhouse, in the first instance, as a ritually constituted structure.

Ritual is described by the Iban in what are largely dramaturgical terms. Ritual is thus 'enacted' (nunda) or 'played' (main) upon a stage; it is performed, that is to say, within a symbolically ordered setting. For the Iban, the longhouse is the pre-eminent setting in which the great majority of rituals are performed. In the course of these performances, architectural and spatial features of the longhouse are assigned signification as elements constituting a dramatic idiom that reflects on aspects of both the visible world and alternative, unseen realities. This process not only makes explicit the basic social and cosmological categories that structure Iban experience, but also evokes the interconnections that exist between them.

In this paper, I briefly consider two major forms of ritual. The first of these consists of rites that centre on the longhouse itself. Included here are rites that accompany house construction and those that establish and preserve the longhouse as a ritual community. The second form of rituals marks major transitions in the human life trajectory. Here, I look specifically at rites of birth and death, showing how each is enacted as a 'journey' (jalai) through the longhouse, its itinerary mapping the major contours of the Iban social and cosmological world.

Two points emerge from looking at the longhouse through a ritual lens. The first is that the longhouse represents a plurality of symbolic orders, not simply a single order 'fixed' in the physical structure of the house itself. These orders are not only multiple, but are also alterable, even at times reversible, and are constantly created and re-created in the course of rituals. Second, the representation of the longhouse that emerges from ritual is very different from that which is conveyed by the existing ethnographic literature. In the latter, the longhouse and its constituent bilik-families are generally represented as independent, essentially autonomous entities. By contrast, ritual locates these groups, as do the Iban themselves, in an ordered series of part- whole relationships. Here, by focusing on ritual, I hope to reveal a more indigenously 
based perception of the longhouse and correct the pervasive bias favouring physicality that has tended, in the Bornean ethnography, to colour our understanding of longhouse sociality and symbolism.

\section{The Iban Longhouse}

The Iban are a vigorous, outwardly expansive people of West-Central Borneo who number some 400000 in the east Malaysian State of Sarawak. Despite increasing urban migration, the great majority live in longhouse settlements along the main rivers and smaller streams of the interior and subcoastal districts. Here most subsist by shifting hill-rice agriculture, supplemented by the cultivation of perennial cash crops, most notably rubber. All speak closely related dialects of a single Ibanic language, part of a larger complex of Bornean Malayic languages (see Adelaar 1985:1-5; Hudson 1970, 1977). ${ }^{1}$ The Iban are divided internally into a number of major riverine groupings. Referred to as 'tribes' in the nineteenth century literature, each of these groupings comprises a loose territorial unit made up of longhouse communities arrayed along the same river or tributary system. The organization of Iban society is bilateral. Descent groups are lacking and marriage is preferentially endogamous within widely ramifying kindred networks. These networks characteristically extend throughout the river region and provide the organizational basis for a variety of individually organized, task-oriented groups (see Freeman 1960, 1961).

The present paper specifically deals with the Saribas Iban population that lives along the Paku River and its tributaries, between the Rimbas and upper Layar rivers, in the lower Second Division of Sarawak (Figure 1). Today, of a total Iban population of some 35000 in the Saribas, the Paku Iban number nearly 4000 and are divided between thirty-three longhouses, ranging in size from six to thirty-nine bilik-families, the mean number being 16.5 (see Sather 1978, 1985, 1988).

The longhouse (rumah) forms the principal local community (see Figure 2). In the Paku all longhouses are located along the banks of the main Paku River and its chief tributaries: the Bangkit, Anyut and Serudit streams. Structurally, each house consists of a series of family apartments arranged side by side. The same term bilik refers to both the longhouse apartment and the family group that occupies it. The bilik-family typically consists of three generations grandparents, a son or daughter, his or her spouse and their children — with membership acquired by birth, marriage, incorporation or adoption (Freeman 1957). Fronting the biliks is a covered, unpartitioned gallery called the ruai. This runs the entire length of the house and, while divided into family sections (each built and maintained by an individual bilik family) the whole is available for communal use. The wall that separates the biliks from the ruai thus bisects the structure into two equal halves (Figure 3). 
Posts, Hearths and Thresholds: The Iban Longhouse as a Ritual Structure

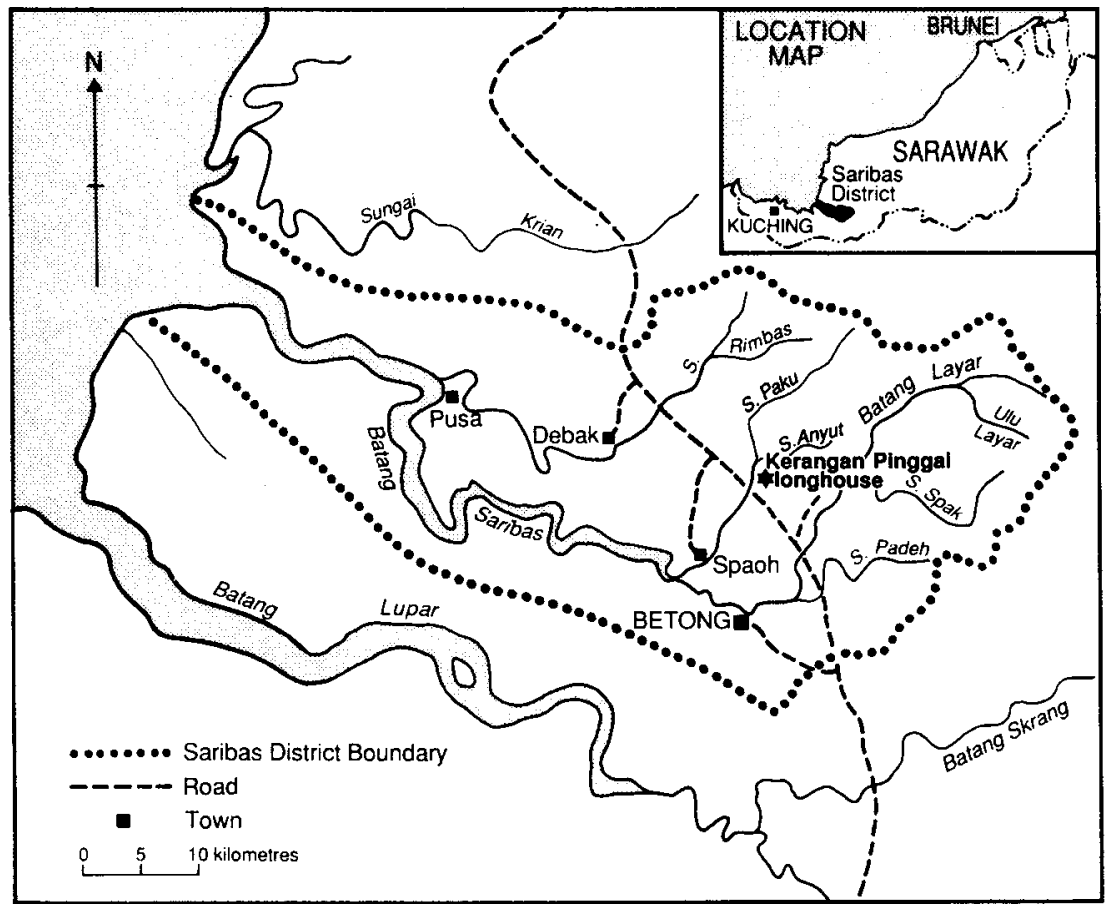

Figure 1. Saribas District

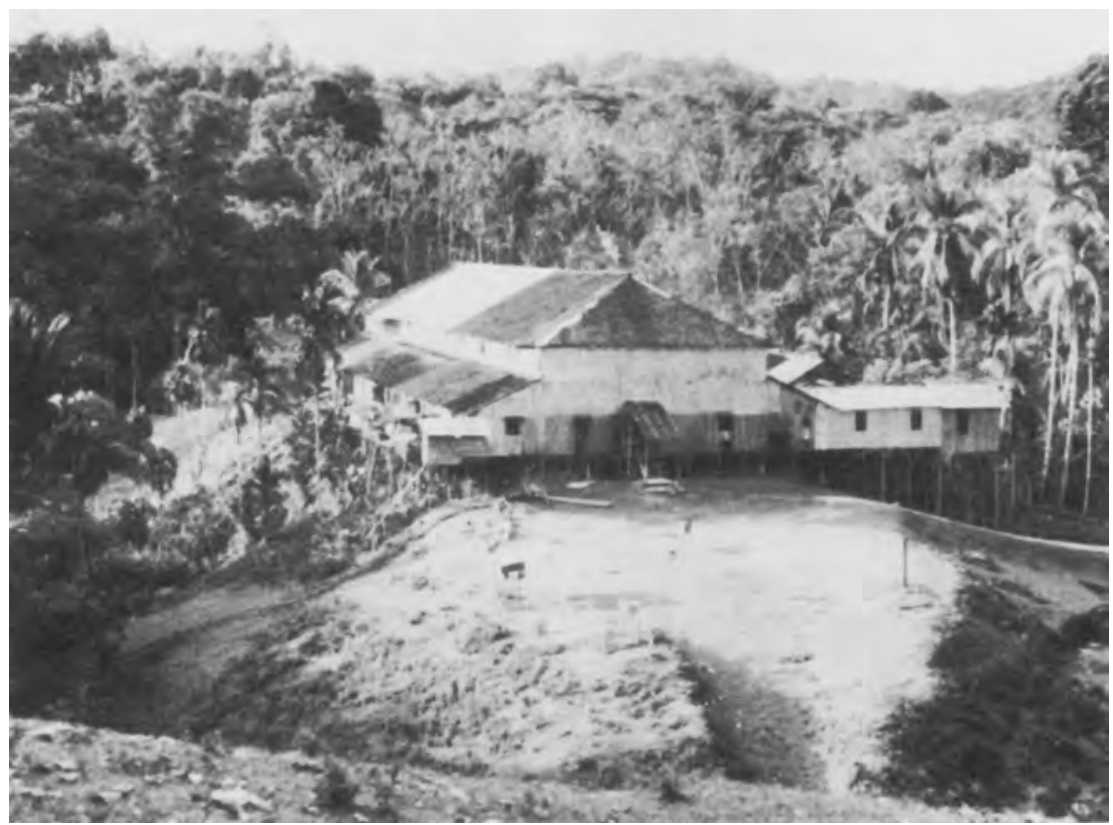

Figure 2. Danau longhouse, Ulu Paku 
On one side of this wall, the bilik apartments represent each family's domestic space, symbolizing its existence as a discrete corporate group, while the unpartitioned gallery on the other side is a public space, symbolizing the longhouse as a whole and its membership in the larger riverine society that encompasses it.

\section{Sources and Elders}

Every Iban longhouse is identified, in the first instance, with a menoa rumah, or territorial domain. ${ }^{2}$ Here, within this territory, individual bilik-families clear their annual farms, grow rice and other food crops, and observe a common body of normative rules (adat) and ritual interdictions (pemali) which are enforced by the longhouse and express its status as the jural and ritual centre of its domain. The continued existence of the longhouse is thought to depend upon its members behaving as these rules and interdictions require (Heppell 1975:303-304; Sather 1980:xxviii-xxxi). Thus breaches of adat and disturbances of the ritual order are said to render a longhouse 'hot' (angat), leaving its inhabitants open to infertility, sickness, death and other calamities.

Until the imposition of Brooke rule, ${ }^{3}$ beginning in the second half of the nineteenth century, 'elders' (tuai) were acknowledged at the level of both the longhouse and the wider river region. Regional leaders, called tuai menoa, were drawn mainly from the raja berani, literally the 'rich and brave', and were self-made men with a reputation for military prowess, resourcefulness and judgment; they acted primarily as peacekeepers, go-betweens and charismatic war chiefs (tau' serang or tau' kayau), mobilizing regional followings for raiding and the territorial defence of the river. With Brooke rule, this former pattern of competitive regional leadership was superseded by the creation of formal administrative districts under officially appointed Penghulu, or 'native chiefs', and today the Penghulu act, together with the longhouse headmen, as the principal intermediaries between the local community and the state (see Freeman 1981:15-24; Sather 1980:xiv-xxviii, n.d.).

Responsibility for safeguarding the normative order that, for the Iban, centres in each longhouse domain, rests chiefly with the longhouse headman (tuai rumah) and other community elders (tuai). The most important of the latter are the tuai bilik (family heads). Thus, in matters of adat, longhouse and bilik elders are said to have 'authority' (kuasa) over or 'to speak for' (jakoka) other longhouse or apartment residents.

Complementing the role of the tuai (elders) in matters of adat is the role of the pun (sources) in matters of ritual and the custodianship of group sacra. When a longhouse is first built, its 'longhouse source' (pun rumah) supervises the rites of house construction. In doing so, he confirms his status as caretaker of its central 'source post' (tiang pemun). This post centres the house both ritually and 
in terms of the internal orientation of its parts. Every longhouse is believed to be susceptible to the intrusion of malevolent spirits and other injurious forces, and to disruptions of its ritual order from within. The task of the pun rumah as custodian of the 'source post' and its associated sacra, is to ward off these dangers and, should its ritual well-being be threatened, to perform rites of 'cooling' (penyelap) on behalf of the community as a whole, by which the longhouse and its domain are restored to a 'cool' (chelap) or benign state.
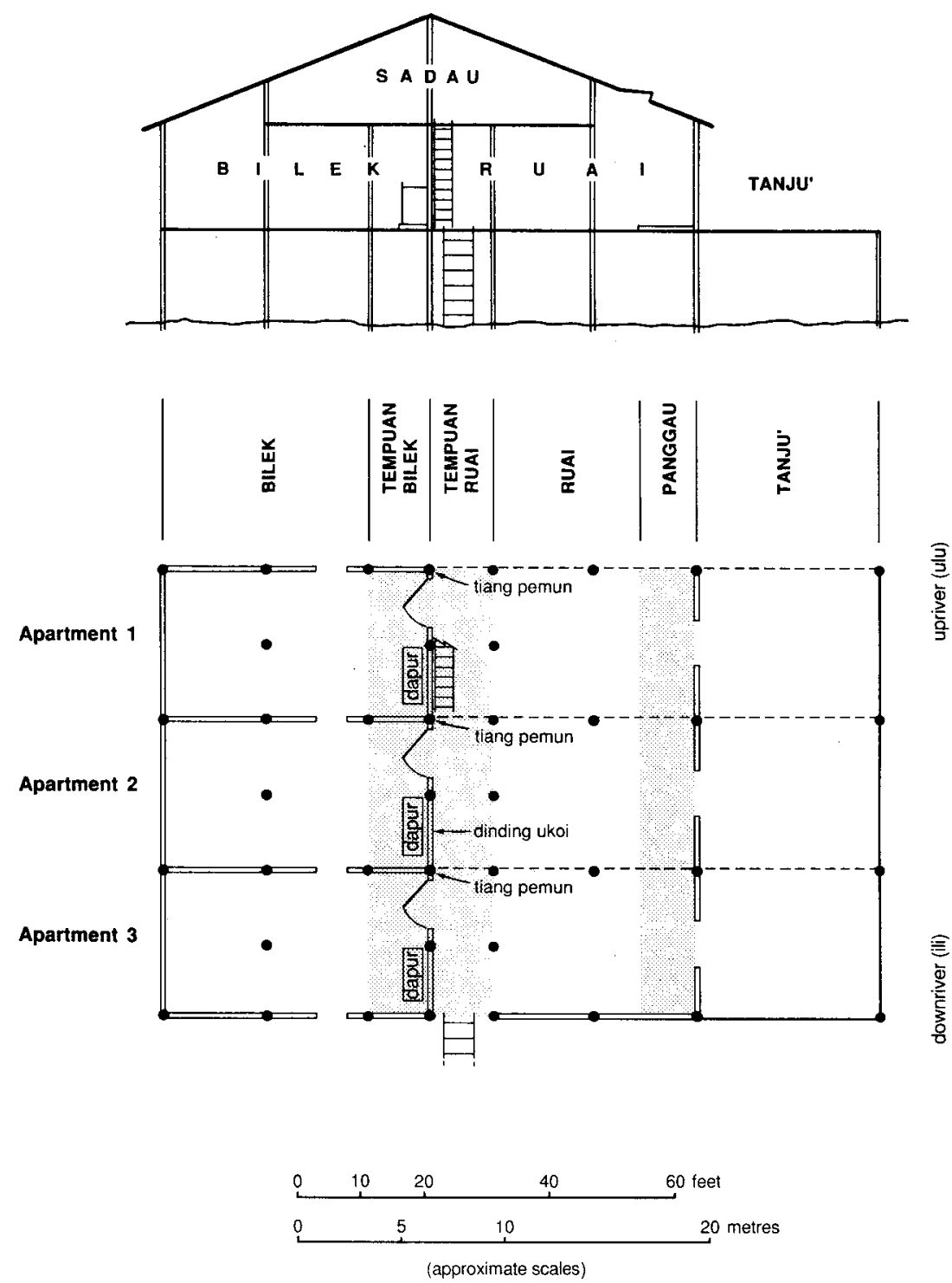

Figure 3. Longhouse section and plan 
Each family, too, has a 'source' (pun bilik). The pun bilik, or family source, is the custodian of the bilik's heritable estate, including ritual sacra that symbolize the continuing life of the family, notably its ritual whetstones (batu umai) and sacred strains of rice (padi pun and padi sangking). The family is ideally an enduring group and the pun bilik personifies its continuity (tampong). As the senior-most family member and the principal heir through whom family wealth and sacra are transmitted, the pun bilik represents the family's living ancestor, the chief link between its present and past generations and the source through whom all family rights devolve.

\section{Hearths and Posts}

Every bilik apartment contains, at its front upriver corner, a tiang pemun, literally a 'source, foundation post' (Figure 3). These posts or pillars are the first to be erected during house construction and, when the longhouse is completed, extend down its central axis to separate the bilik apartments from the unpartitioned gallery. Each family's tiang pemun is under the care of its pun bilik (family source).

However, there is also a central tiang pemun which, together with its caretaker, the pun rumah, takes ritual priority over all the others. This central tiang pemun is the first post to be raised during house construction and is not only the 'source post' of the pun rumah's bilik, but represents the primary 'foundation pillar' for the longhouse as a whole. It is through the rites of 'fixing' (ngentak) this post that the longhouse is established as the ritual centre of its domain and the pun rumah is confirmed as its living 'source'.

As custodian of the central tiang pemun, the pun rumah is said to 'own' (empu) the adat genselan, the ritual rules and offerings associated with the post. These rules preserve the longhouse in a state of ritual well-being and include procedures, such as sacrifice and blood lustration (enselan) meant to repair disturbances of its ritual harmony, performed particularly at the central tiang pemun, but also at other parts of the longhouse, especially at its entry ladders and the tempuan passageway. The pun rumah is also entitled to collect fines (tunggu) from those whose actions break ritual interdictions or in other ways endanger the community's state of ritual well-being. Thus, for example, if a longhouse member dies while outside the house, before his or her body - now a source of 'heat' - can be carried inside, the members of the bereaved family must first sacrifice a pig (or two chickens). This is done under the direction of the pun rumah at the base of the longhouse entry ladder (kaki tangga' rumah). The pun rumah then lustrates the tiang pemun with the blood, which is also smeared on the earth at the foot of the house ladder, and on the bottoms of the feet of those who carry the body into the house. In addition, the family must pay a genselan fine to the pun rumah. Many other acts such as adultery, quarrelling, cursing, threatening others (nyakat) or drawing a weapon in anger, 
when committed inside the longhouse, require sacrifice, offerings and the blood lustration of the central tiang pemun. Among the most important of these genselan rules, however, are those which sanction the adat dapur (family hearth rules). These rules unite the longhouse ritually and preserve its family hearths, in contrast to the tiang pemuns, in an antithetical state of 'heatedness' (angat).

The ritual priority of the central tiang pemun is thus established at the start of house construction. The rites that initiate construction are called ngentak rumah, literally 'to fix' or 'drive in the longhouse'. ${ }^{5}$ During ngentak rumah the main tiang pemuns are 'driven into' (ngentak) the earth. This is the sole 'work' (pengawa') undertaken during ngentak rumah and is performed by a ceremonial work party comprising longhouse men and male guests from neighbouring longhouse. The work is overseen by the pun rumah whose central tiang pemun is the first post to be 'driven in'. It is also the main focus of the ngentak rites.

Ngentak rumah begins with the ritual bathing (mandi') of the central tiang pemun by a group of senior women. This act closely parallels the ritual bathing of a new-born infant to mark its entry into the longhouse community (Sather 1988). Bathing is said to 'cool' the post. Later, to mark the completion of house construction, the entire structure is ritually 'bathed' (mandi' rumah). After the central tiang pemun has been bathed, it is scattered with popped rice, oiled and, beginning at its base, smeared with the blood of a chicken. The gods are then invoked, notably the gods of the earth, Simpulang Gana and Raja Samarugah, and the antu dapur, the tutelary hearth spirits. To affirm his ownership of the adat genselan, the pun rumah sacrifices a pig. Its blood and severed head, together with other ritual objects, ${ }^{6}$ are placed in the hole into which the central tiang pemun is then driven. After this has been raised, the tiang pemun of each of the individual biliks is erected in sequential order, moving outward from the central tiang pemun, first downriver and then upriver, ending with the final tiang pemun at the upriver end of the house. For a small house, the entire ritual may be completed in one day. For a larger house, the first day is generally spent raising the downriver posts; the second day, the upriver posts.

As caretaker of the central tiang pemun, the pun rumah personifies the living ancestor of the longhouse, just as the pun bilik embodies the living ancestor of the bilik-family. Ideally the original pun rumah and his successors should be able to trace their genealogical connections to the pioneer founders of the community, also known as pun, who first cleared its domain of primary forest, through an unbroken line (or lines) of ascent. The pun rumah's genealogy (tusut) should thus serve, ideally, as the main line or batang tusut ('trunk genealogy') by which other longhouse members trace their connections to the community's ancestors. ${ }^{7}$

While the relationship between the pun rumah and pun bilik is established through the ritual priority of the central tiang pemun, the relationship between 
the tuai rumah and tuai bilik is expressed most clearly in the ritual rules that surround the installation and use of the family hearths.

An Iban hearth (dapur) consists of an earth-filled firebox (entilang), supported in a frame (para') whose posts extend through the house floor directly into the earth below. Above the hearth is a rack for storing and drying firewood and for keeping the family's salt stores (telak garam). Traditionally the hearth was constructed immediately behind the front wall of the bilik, inside an area of the family apartment called the tempuan bilik (Figure 3). (Today most hearths are built at the rear of the bilik in a separate cooking area.) Being of earth, the dapur is said to belong to Simpulang Gana, the Iban god of the earth. In Paku myths, Simpulang Gana acquired dominion over the earth by inheriting the dapur of his father Raja Jembu after the other gods, in his absence, had divided the family's magical sacra among themselves, leaving Simpulang Gana without a share except for the hearth (Harrisson and Sandin 1966:261-262; Sandin 1967a; Sather 1985:34). The hearth is also associated with the antu dapur, the tutelary hearth spirits. All of those who make use of the same hearth are said to come under the authority of the tuai bilik, including visitors and temporary guests residing in the family apartment. Within the longhouse, the hearths represent the principal link between the bilik-family and the longhouse's menoa. This link is signified by the earth from which the dapur is made and by the hierarchy of authority that extends as a result of its use from bilik elders, through the headman, to the god Simpulang Gana, the earth's 'owner'.

This hierarchy of authority is established in respect of the hearths through the rites of house construction. As soon as the new longhouse is completed a ceremonial 'moving in' (pindah) takes place. This is followed by the 'bathing of the house' (mandi' rumah) and, in the past at least, by a ritual 'striking of posts' (gawai pangkong tiang). The latter accompanies the setting in place of the ridge-capping (perabong) along the top of the longhouse roof. This capping 'completes' the structure. 'Moving in' precedes the 'striking of posts' and is initiated by a ritual installation of the family hearths. During pindah each family carries its possessions into the longhouse in a prescribed order, beginning with mats (tikai) and ending with trophy heads (antu pala') and weaving-looms (tumpoh) (see Richards 1981:312). The entry of each family is in order of the precedence established during ngentak rumah when each family's tiang pemun was erected. ${ }^{8}$ This order determines, in Iban terms, relative relations of 'who went first' (orang ke-dulu). Possessions are carried into the house by both the upriver and downriver entrances, so that ideally they are never carried past the central tiang pemun nor past one another in violation of their upriver-downriver order, that is to say, 'across', or 'in front of' (meraka) those who 'went first' $(k e-d u l u)^{9}$ in erecting their 'source post'. 
Before pindah begins, the members of each bilik-family collect earth (tanah) from the longhouse menoa and mix it with earth taken from the family's previous hearth to make the new dapur. At the start of pindah, the earthen firebox is carried into the longhouse and installed by the tuai bilik in the newly constructed hearth frame. After all families have installed their hearths, the first fire is lit by the tuai rumah. ${ }^{10}$ The other families then take their first fires from the headman's dapur, thereby establishing the latter's priority.

The installation of the hearths binds the separate bilik-families together into a single ritual and adat community. From the time the hearths are installed in the house until the structure is dismantled and replaced by a new one, they must not be allowed to grow 'cold' (chelap). A 'cold' hearth signifies an unoccupied apartment, indicating, in turn, the family's withdrawal from the community (neju' ka rumah). To prevent the hearth from growing 'cold', a fire must be lit and rice cooked on the dapur at least twice each lunar month: at anak bulan (new moon) and bulan pernama (full moon). A 'standin' (pengari) may be employed to cook rice on the hearth not more than once each lunar cycle. ${ }^{11}$ Should a family fail to keep its hearth 'warm', the family 'elder' must pay adat genselan and make offerings to the central tiang pemun. Observance of the hearth rules prevents the permanent dispersal of longhouse families and so keeps them from leaving the community without first paying compensation for the ritual damage their departure causes. Following the installation of its hearth, should a family subsequently break the ritual unity of the community by moving to another, its members must pay both genselan and adat fines. In addition they must also make offerings to the central tiang pemun and perform a ritual 'throwing away of the hearth' (muai dapur). This 'throwing away of the hearth' marks their formal withdrawal and restores the ritual solidarity of the remaining community. Only by maintaining a bilik hearth may a family exercise membership in the longhouse community and cultivate land within its menoa.

As a final ritual act, the community may perform a 'striking of the post' festival. Once house construction is completed, the tiang pemuns, as corner posts, are typically enclosed behind bilik walls, so that on public occasions their place is usually taken by the exposed pillar at the edge of the tempuan passageway between adjacent biliks (Figure 3). During the 'striking of the post' ritual, the base of each of these pillars is wrapped in pua' kumbu' cloth to form a series of bilik altar-places (pandong) around which the bards circle as they sing the gawai chants. At the pillar representing the central post, a man conceals himself inside the cloth enclosure. Here he speaks the part of the principal tiang pemun as the pillar is struck (pangkong) by a bamboo tube containing cooked rice, promising wealth and spiritual well-being to the members of the house. The festival thus highlights the ritual significance of the tiang pemun in safeguarding community well-being and the relation of precedence that exists between the central longhouse post and the individual source posts of each family. 


\section{Upriver, Downriver, Parts and Wholes}

As riparian settlements, Iban longhouses are built along rivers and streams with their long axis ideally oriented parallel to the main river course. Consequently, the two ends of a longhouse are normally distinguished as the 'upriver' (ulu) and 'downriver' (ili') ends. ${ }^{12}$ This orientation, as well as the presence of a centralizing 'source', is basic and is evoked constantly in everyday speech. Thus the location of an individual's apartment is characteristically indicated by its position vis-à -vis the upriver or downriver end of the longhouse; that is, as being within its upriver or downriver 'half' (sapiak), at the head of one or the other of its entry ladders (pala' tangga'), or as so many biliks from its upriver or downriver end.

The distinction between upriver and downriver functions, in particular, with respect to the location of the pun rumah's bilik. During house construction, the pun rumah is expected to locate the door to his bilik apartment on the downriver side of the central tiang pemun. ${ }^{13}$ Thus, the central tiang pemun serves as the corner post between the pun rumah's bilik and the next bilik upriver. The pun rumah locates his bilik hearth on the downriver side of his door, while, on the downriver side of his hearth, the tiang pemun of his downriver neighbour similarly forms the corner post between his own and the latter's apartment (Figure 3). This orientation of bilik posts one to another thus identifies the bilik, in the first instance, as a constituent of the longhouse, with the central tiang pemun to which each bilik post is oriented representing the longhouse as the overriding totality.

The way the longhouse is constructed clearly represents this whole-part relationship between the longhouse and the bilik. During ngentak rumah, beginning with the raising of the central tiang pemun, the order in which the other tiang pemuns representing particular biliks are erected reflects the order of precedence existing among the biliks themselves, moving outward in sequence - first downriver and then upriver - from the house's central post. Each family's tiang pemun is thus located at the upriver corner of its apartment, separated by a door and hearth from the tiang pemun of its downriver neighbour (Figure 3). Thus the tiang pemun is clearly a threshold marker. It is located at the juncture (antara) between individual biliks and between the bilik and the gallery. The location of individual biliks relative to one another, and by way of their common orientation to the central apartment of the pun rumah, clearly identifies the bilik, not as a free-standing entity, but as the component member of an encompassing whole.

This encompassment is marked in two other ways as well: firstly, by the side-walls that separate one apartment from another and secondly, by the rules of adat genselan. During house construction, only the pun rumah erects two side-walls, one on each side of his bilik apartment. All other biliks erect only 
one side-wall, on either the upriver or downriver side of their apartment, depending on the bilik's location relative to that of the pun rumah. Similarly, each apartment stands on three rows of posts: one central row and two side rows shared by neighbouring biliks (Figure 3). Only the pun rumah erects all three rows; every other bilik erects only two, the central row and either an upriver or downriver row, depending, again, on its location relative to that of the pun rumah. Thus the longhouse shares a common orientational centre and is perceived as growing outwards laterally, or bilaterally, from each side of the pun rumah's apartment. The lateral addition of bilik apartments to the longhouse, both during and after its initial construction, is referred to by the same term, tampong, as the generational succession of bilik members through time, with the pun rumah serving as the primary reference point in the first process of growth, the pun bilik in the second.

Finally, the pun rumah, by performing sacrifice during ngentak rumah, binds the longhouse together as a ritual community so that if a family should subsequently break this unity by withdrawing, its members must ritually remove their hearth, pay genselan and present offerings at the central tiang pemun in order to restore ritual harmony to the community.

\section{Trunk, Base and Tip}

The distinction between upriver and downriver is allied with another between 'base' and 'tip'. Anything that has both a base and a tip (or tips), or forms the main member of a totality composed of parts, is called a batang or 'trunk'. Thus both the longhouse and the main river on which it is located are described as batang. Like the trunk of a living tree, both rivers and longhouses are seen as extending between a beginning point - a source or 'base' (pun); and an end point or points - a destination or 'tip(s)' (ujong or puchok). ${ }^{14}$ At one level the metaphor is botanical and spatial. For a river, its 'base' is downriver at its mouth, and its 'tip' is upriver at its headwaters. ${ }^{15}$ But the metaphor is also totalizing. Thus the Paku Iban refer to the entire Paku River region - including both its main river and tributaries (sungai) and all of its inhabitants taken together - as sekayu batang Paku, literally, 'the whole of the Paku trunk'.

For the Iban, the notion of source or origin is signified by the term pun, or by related forms such as pemun. Literally, pun means source, basis, origin or cause (see Richards 1981:290). 'Its root meaning is that of stem, as of a tree' (Freeman 1981:31). In terms of social actors, pun describes a person who initiates or originates an action; one who announces its purpose and enlists others to participate in bringing it about. Pun, in this sense, has the meaning of 'founder' or 'initiator'. Most groups formed by pun are ephemeral. But some, like the longhouse and the bilik-family, endure. Once an enduring group takes form, the pun becomes, like the pun rumah and pun bilik, the 'source' through whom its continuing life is thought to flow from one generation to the next. Thus the 
notion of pun incorporates a sense of both origin and continuity (Sather n.d.). Similarly, 'trunk' represents the entirety of a process, from its initiation to its realization, from beginning to end, from - to follow the botanic metaphor 'stem' to 'tip'.

Situated between downriver and upriver, the longhouse is also constituted, like the river itself, as a batang. Similarly, the ordering of its parts mirrors that of a living tree. The timbers employed in its construction are placed so that their natural 'base' is down or towards the pun of the house, and their natural 'tip' is up or towards its ujong, reflecting the orientation that the wood originally had in its forest setting. Thus when trees are felled and cut into timbers, the pun end of each timber is marked so that its correct orientation can be preserved. Similarly, the central tiang pemun represents a centralizing 'base' or 'stem'. It is this central base that 'fixes' the house, that is, determines the order of the other parts, while it is from its lateral 'ends', the upriver and downriver 'tips' of the house, that the longhouse continues to 'grow' or 'extend' (tampong), adding new biliks as established households undergo partition or as new families join the community. The imagery of 'origin', 'tip' and 'trunk' is thus not merely classificatory, but essentially processual as well as botanic in nature.

The rituals of house construction not only make these base-tip relationships explicit, but assign them a temporal ordering as well. Thus the central tiang pemun is the first pillar to be erected. Ideally, it is located near the centre of the house and is driven into the earth, or 'fixed', base-first, its natural base-end downward and its natural tip upward. The latter, together with the 'tips' of the other tiang pemun, support the ridge-capping (perabong) at the highest point of the house. In temporal terms, this capping is the last part of the house to be constructed following the erection of the entry ladders at each end. Fixed to the 'tips' of the 'source posts', it ritually marks the structure's completion. When the central post is bathed, oiled and lustrated before being raised, these acts, too, are performed base-first, while the offerings that affirm the post's ritual status are buried in the earth beneath its base and explicitly symbolize this idea of 'rootedness' ${ }^{16}$ Finally, once this centralizing 'base' is located, the secondary tiang pemun are erected in order, first extending downriver from the central post and then upriver, establishing in this way a temporal relationship between the 'base' of the house and its lateral 'tips'. At the same time, in moving upriver and downriver, the 'tips' are associated in a mirror-like reversible relationship, extending bidirectionally from a single centralizing 'source'. Symbolizing the 'stem' or origin of the house, this central source takes ritual priority over the tips, 'coming before' them in time (ke-dulu), while the latter are essentially co-equal and represent, for the house, points of new or continuing growth.

Finally, while the ordering of the tiang pemuns creates an image of the longhouse as an upright tree, with a central 'base' (pun) and 'tips' (ujong) that 
grow outward at each of its lateral ends, the longhouse may be also conceived of as a tree lying down, with its 'base' at one end and its 'tip' at the other end. Both images correspond to the natural orientation of the wood used in the house's construction. The contrast between them is shown in Figure 4. ${ }^{17}$ Both images apply not to the upstanding tiang, but to the second major category of building material, the ramu, horizontal elements, specifically in this case, its lengthwise beams. The first image represents the longhouse as originating from a central pun, its ramu growing outward, bilaterally, towards both a downriver (ili') and an upriver (ulu) ujong (Figure 4, Type I). This is the characteristic orientation of houses in the upper Paku. In the second image, the longhouse represents a tree trunk lying down with either a downriver pun and an upriver ujong or alternatively if the direction of the wood is reversed, an upriver pun and a downriver ujong (Figure 4, Type II).

The direction in which the pun points is determined by the arrangement of the mortice-and-tenon joints by which one beam is joined to another as they are slotted through the main support pillars, including the tiang pemun. In each joint there is an upper and lower tenon, and these are always arrayed in the same direction throughout the structure. The Iban say that the pun 'falls on' (ninggang) the ujong. Thus the pun end of the ramu forms the upper tenon and the ujong end, the lower tenon, corresponding to a series of trees fallen, end-to-tip, with the base of one 'falling upon' the tip of the next, so that the base of each beam points in the same direction, either upriver $(k u l u)$ or downriver (kili') (Figure 4). The direction in all cases applies, moreover, not only to the individual beams, but in a totalizing sense to the longhouse as a whole, thus establishing one of its ends as its pun, the other as its ujong, or, more commonly in the Paku, establishing a central pun with a pair of lateral ujong (Figure 4). For the Skrang Iban, Uchibori (1978:93) maintains that the pun end of the longhouse is always upriver and the ujong end always downriver, and that the pun end is welcoming and the ujong end polluting. ${ }^{18}$ In the Paku and Rimbas, however, while some houses have an upriver pun, others have a downriver pun, while yet others have a central pun and both ends are ujong. The same symbolism nonetheless applies in all three cases. Thus, for example, if a bilik-family withdraws from the longhouse, its hearth, when removed, is always 'thrown away' (muai) from the ujong end of the structure, whether this is upriver or down. Similarly, the pun is also ritually marked so that, for example, when the bards call for the coming of the spirit heroes while singing the besugi sakit songs, they hang the swing on which they sit so that it faces towards the pun ramu, whether this is centrally oriented or toward one or the other end of the house. 


\section{Type I}

Pun ramu oriented towards the central tiang pemun; thus an image of the longhouse as an upright tree, with a central base and lateral tips.

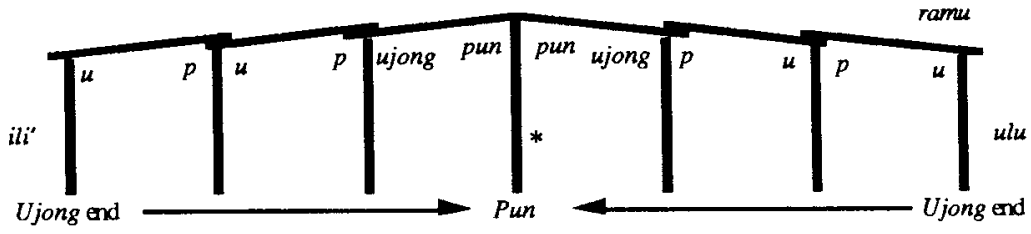

Type II

IIa. Ninggang kili'. The pun ramu 'falls on' (ninggang), or rests upon the ujong end, so that the pun points towards ili' (downriver); that is, presenting an image of the longhouse as a tree lying down with its base downriver and its tip upriver.

Enlargement of the mortice-and-tenon joint

by which ramu (horizontal timbers) are joined.

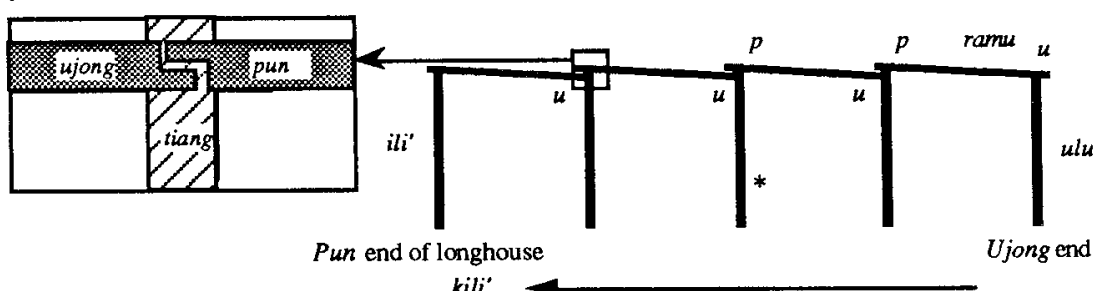

IIb. Ninggang kulu. The pun ramu 'falls upon' the ujong end so that the pun points towards $u l u$ (upriver); that is, as a tree lying down with its base upriver and its tip downriver.

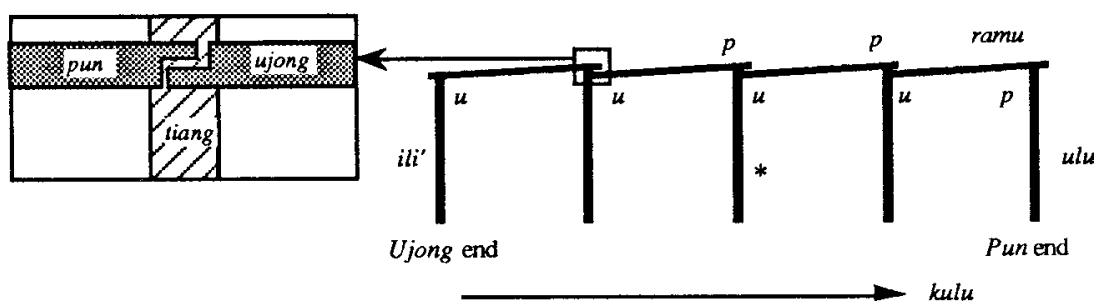

Figure 4. The pun-ujong (source-tip) orientation of the longhouse

\section{East and West}

Architectural space is temporalized in still another way. A second basic orientation of the longhouse is in terms of the sun's movement through the sky from east to west. In Iban east is called matahari tumboh, literally, 'the direction of the growing sun', ${ }^{19}$ and west, matahari padam, 'the direction of the extinguished sun' ${ }^{20}$ In ritual contexts, east is associated with life, particularly 
its beginnings, ${ }^{21}$ and west with death. So far as the longhouse is concerned, the basic notion is that the east-west course of the sun, as it journeys from horizon to horizon (tisau langit), must never coincide with the long axis of the house, such that the sun shines into one or the other end of the structure. Otherwise the community is rendered perpetually 'hot' (angat). A house, instead, should mirror the sun's movement within the cosmos. That is, the sun should orbit the house; it should ascend the slope of the roof from the gallery side, reaching its highest point (rabong hari, 'zenith'), directly over the central ridge-capping (perabong) immediately above the tiang pemun, and then descend again as it follows the slope of the roof downward to the horizon, at the back of the family apartments. In other words, the east-west movement of the sun over the longhouse should cross-cut its internal upriver-downriver divisions.

The gallery side of the house should thus ideally face eastward, in the direction of the rising sun. In most houses the gallery side opens onto an unroofed veranda called the tanju' (Figure 3). The tanju' is strongly associated with the sun and with the daylight phase (hari) of the diurnal cycle. In contrast, the interior of the house is associated with night (malam) and, in ritual contexts, with its inversion: daylight in the unseen world of the souls, gods and spirits. Thus rituals performed on the tanju' characteristically take place during the day, particularly in its early morning hours, while those held inside the house are typically performed in the evening or at night and recreate their inversions, early morning or day in the unseen world.

\section{The Longhouse Bathing Place}

The principal point of entry to the longhouse is its penai' (river bathing place) (Figure 5). ${ }^{22}$ Here canoes are typically tied up, women draw water for household use, and longhouse members bathe. Symbolically, the penai' represents the outer threshold of the community. Thus whenever a house is undergoing a 'cooling' ritual, signs are placed at its penai' to notify would-be visitors that the longhouse is temporarily taboo to guests. Otherwise, visitors enter the community by way of the bathing place, first bathing at the penai' before being welcomed into the house by their hosts. On major ritual occasions, this welcome takes the form of a ceremonial procession. The ritual entry of a newborn infant into the longhouse is marked by a river bathing (meri' anak mandi') similarly structured around a processional welcome to and from the community's penai' (Sather 1988). Following death, the soul of the dead retraces this journey, taking leave of 'this world' the visible world of the living - by way of the same bathing-place through which, as an infant, it made its initial ritual entry.

In so far as biliks are built upriver and downriver, the longhouse itself is construed, like the river to which it is oriented, as a totality produced in time; a unity of parts related by the botanic-morphological metaphor of 'base', 'tips' and 'trunk'. Moreover, just as each bilik is part of the longhouse, so each 
longhouse, too, is part of a larger whole. Each local community is named, and so individuated, by reference to a specific topographic feature ${ }^{23}$ which places it within a landscape, the dimensions of which are defined by the configuration of the main river (and tributaries) on which it is built. Thus situated, each longhouse is positioned within a social universe of upriver and downriver neighbours, the ultimate limits of which are defined by the river system itself, its totality metaphorically envisioned as an encompassing batang or 'trunk'.

Since most travel was traditionally by river, the location of a longhouse within this system of rivers and streams establishes the basic social identity of its members. Surrounding the longhouse are neighbouring houses bound to one another as 'co-feasters' (sapemakai), ${ }^{24}$ allies who alternately act as ritual hosts and guests during major bardic rituals (gawai). Traditionally, in addition to feasting together, a community's sapemakai were its principal allies in warfare and raiding, directing their attacks against enemies living outside their home river system. Thus the horizons of the river also define a further dichotomy distinguishing, very roughly, one's own river, sapemakai allies and kindred, from the rest of the world, enemies and strangers. ${ }^{25}$

Within this river-defined social universe, each longhouse's penai' serves as the nodal point in a network of river travel, with the river itself defining the horizons within which human undertakings are seen as occurring. For men, reputations derive mainly from ventures undertaken as a result of travel beyond their home river: leading migrations, pioneering new domains, warfare or trading, for example. Rivers in turn are conceptualized in terms of a temporalizing metaphor, as flowing between a 'stem' (source) and outer 'tips' (Figure 5). In death this metaphoric association of life and river travel is symbolically expressed through the soul's journey from this world to the Otherworld of the dead (menoa sebayan). Thus, in death, the soul leaves its home longhouse and travels first downriver to the river mouth and then upriver to its headwaters, making a total river circuit from horizon to horizon before entering the Otherworld of the dead, itself conceived of as a river system (Batang Mandai). ${ }^{26}$ This journey which is ritually represented in the poem of lamentation sung over the dead precisely replicates the temporal ordering of the longhouse itself, as represented by the order of its 'source posts': first downriver, then upriver and ending, most remotely from its central 'source', at its upriver 'tip'. But in death this journey is reversed and its tips form a mirror-like image so that the final destination of the soul's journey becomes, in the transposed Otherworld of the dead, a new beginning, and its end, a new 'source'. 

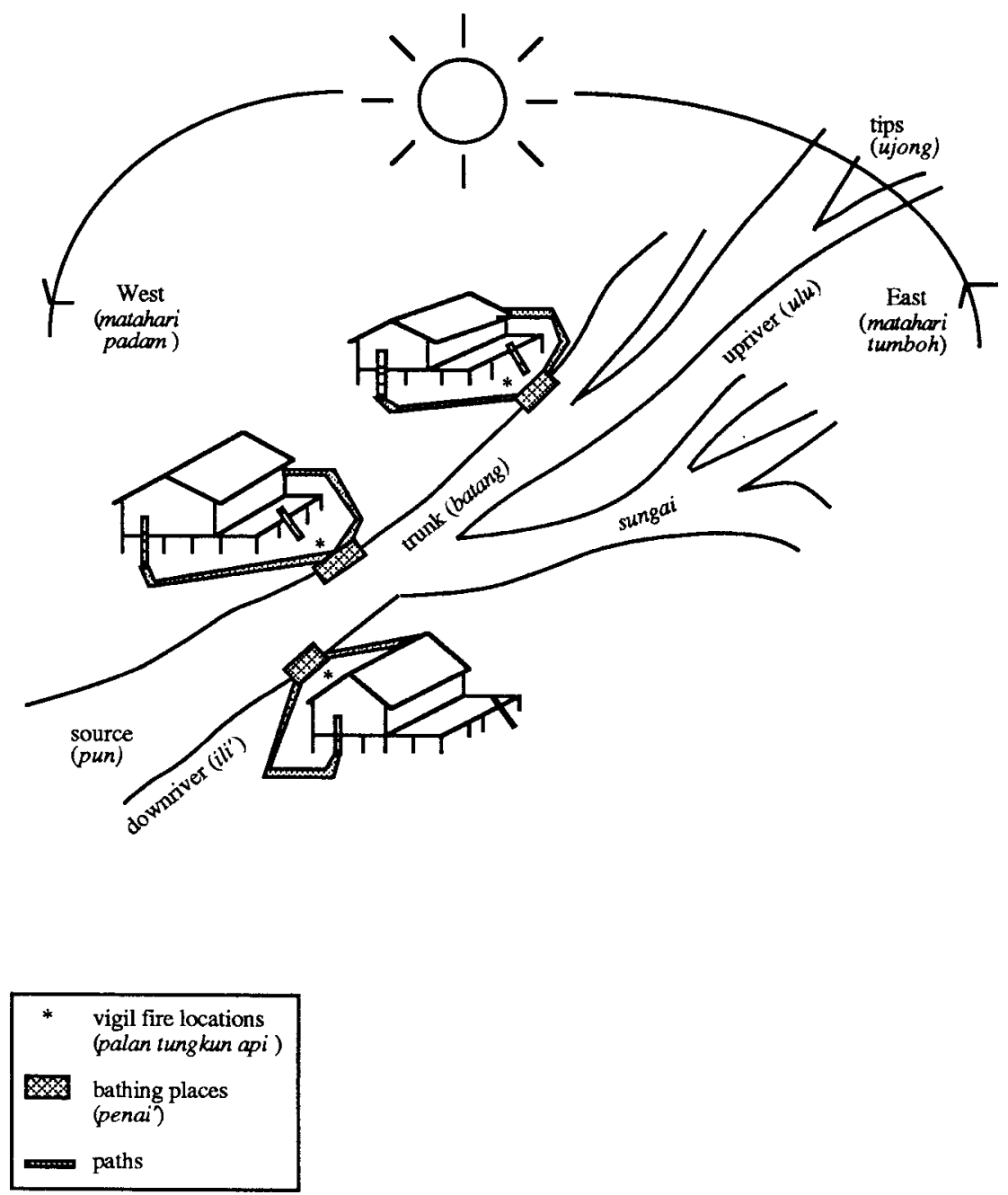

Figure 5. Longhouse orientation

\section{Interior Architecture}

The principal internal division of the longhouse is produced by the 'dog wall' ${ }^{27}$ This is attached to the tiang pemuns and, extending down the centre of the house, divides the biliks from the ruai. Each bilik is entered through a door (pintu) in this wall from a common passageway, the tempuan ruai, that runs from one end of the longhouse to the other (Figure 2). The 'dog wall' itself bisects the intermediating tempuan zone into bilik and ruai sections. From each end of the tempuan ruai an entry ladder (tangga' rumah) typically descends to the ground. A low side-wall, usually containing an opening through which neighbours may converse or pass objects, separates adjoining biliks. Beyond the tempuan ruai, the main gallery extends to the opposite eaves of the house. In contrast to the 
bilik the gallery constitutes the primary setting for public gatherings and rituals and is the centre of longhouse, as opposed to family, sociability. Here visitors are received and entertained, and in the evenings, as families return from their fields, the area becomes a common work place where mats and baskets are woven and tools repaired, and where families exchange news.

The ruai contains an 'upper' (atas) and 'lower' (baroh) zone, each defined by the location of pillars (Figure 3). An identical division applies to the bilik. ${ }^{28}$ Considered together, the bilik is conceptually 'lower' than the ruai, while the upper gallery is the 'highest' of these zones and the central tempuan the 'lowest'. Thus the arrangement of upper and lower zones cross-cuts the upriver and downriver divisions of the longhouse. Like the house's 'stem' and 'tips', these zones are bilaterally oriented, the inner mid-zone being 'lower' and the opposed outer zones, 'upper' ${ }^{29}$ The uppermost section of the gallery is called the panggau (or pantar) and is usually covered by a raised platform further emphasizing its elevation (Figure 3). Here male visitors are seated (see photograph on p.64) and at night the area traditionally served as the sleeping place of unmarried men. ${ }^{30}$ While the upper gallery represents the 'highest' point within the longhouse interior, the open-air veranda (tanju') is described as being 'above' (ke-atas) the upper gallery. It is reached at each family section by a doorway from the gallery-side of the house and in terms of its cardinal orientation, ideally faces eastward. ${ }^{31}$ Furthering the botanic imagery of the longhouse, the point at which the gallery and veranda meet is known as the pugu' tanju', the 'rootstock of the veranda'.

The longhouse interior is marked by vertical as well as horizontal gradients. In addition to the conceptual gradients arrayed across the house, the bilik itself is divided between an upper and a lower region, the family apartment and a loft (sadau) which is built above it and is reached by an entry ladder from the tempuan passageway (today more commonly from the interior of the bilik) (see Figure 3). Here the family stores its harvested rice in large bark-bin granaries. These granaries are above the family's hearth; thus smoke from the family's dapur, filtering through the centre of the loft, is said to warm the rice. While domestic life tends to centre on the bilik and public affairs on the ruai (see Sutlive 1978:55), the distinction between the apartment and the loft above it is associated with a woman's ordinary domestic tasks and with female prestige and fecundity. Sexual segregation is notably lacking in Iban society and women, like men, compete for status and renown. The loft, in particular, is identified with the activities by which women distinguish themselves; namely, weaving and rice agriculture. Women set up their looms, spin thread, dye and weave cloth in the loft, and here the senior women of the family store the bilik's seed-rice, including the seeds of its sacred padi pun. In addition, the loft was traditionally the sleeping 
place of women of marriageable age. Here, at night, they received suitors and conducted amours.

Finally, the two major zones of the longhouse interior, set apart by the 'dog wall', are associated with different levels of social integration. The bilik side marks both the individual bilik as an entity and the longhouse as a totality having individual biliks as its constituents; the gallery side marks both the longhouse as a unit and the larger riverine society as a totality having individual longhouses as its constituents. Hence the gallery side of the longhouse is unpartitioned, while the bilik side is divided (by secondary walls) into separate, but conjoined apartments. The point of conjunction that joins all of these divisions is formed by the central tiang pemun and by the row of secondary tiang pemuns that extends bilaterally from it, upriver and downriver.

\section{The Ritual Use of Longhouse Space}

Ritual brings into play, at different times, each of the major structural levels represented in the ritual and physical constitution of the longhouse. Thus the Iban divide the greater part of their ritual activity into three major categories: bedara', gawa', and gawai (see Masing 1981:34-55; Sandin 1980:40-42; Sather 1988:157-159). The bedara' are essentially bilik-family rites, small thanksgiving or propitiation rituals held, for example, to nullify ill omens or acknowledge spiritual favours. The Iban distinguish between bedara' mata' (unripe bedara'), and bedara' mansau (ripe bedara'). The first are held inside the family apartment, the second on the longhouse gallery. The movement from apartment to gallery marks an increase in the seriousness of the ritual and a shift in its social focus from the family as a separate entity to the family as a part of the longhouse community. The gawa' are essentially longhouse rituals of intermediate complexity, while the gawai are major bardic rites, witnessed by guests drawn from the larger river region, including the community's sapemakai (co-feasting allies). Both are performed on the gallery.

The distinction between these three broad classes of ritual reflects not only social structure but also the processes by which each individual is incorporated into the social and ritual order itself. From birth, Iban children are prepared for participation in ritual activity. Beginning by taking part in small bedara' offerings made inside the family apartment, a child's ritual incorporation gradually extends outward to include participation in major longhouse and gawai rituals. Only as an adult, however, is a person empowered to act as a ritual sponsor, and maturity marks the beginning, for both men and women, of a life-long quest for recognition of spiritual favour, prestige, power and reputation, pursued largely by ritual means (Sather n.d.).

This process of incorporation and the movement of the individual through the social and ritual order are marked by transformations in the ritual 
organization of the longhouse itself, the attribution of alternative meanings to its spatial and architectural features. Iban rituals are characteristically structured as journeys (jalai) and meanings are conveyed through images arranged linearly, in space and time, to create an itinerary of travel or movement. Thus each person's life trajectory from birth to death is enacted as a series of journeys through the longhouse itself, with significant transitions signalled within this setting by scene changes, the entry and exit of actors, and by ritual processions, inversions and transformations of staging, time and scenery.

Underlying these processes, Iban categories of phenomenal experience posit two parallel realities (see Barrett 1993). The first comprises a wide-awake reality in which each person acts bodily within a social world constituted of other living persons. The second consists of a dream reality in which the soul, ordinarily unseen, interacts with other souls, the spirits, spirit-heroes and gods. The performed reality evoked by ritual reflects on both these parallel realities, creating a mediation in which relations between the two are made explicit, merged, reversed and transformed in ways which, for the Iban, not only 'reflect on' these realities but are instrumental as well, signalling transitions and producing consequences within the phenomenal worlds they evoke.

\section{Rites of Birth}

Iban rites of birth clearly illustrate these processes. At birth the mother and infant are confined to the bilik apartment. Here, following delivery, the mother is subject to a period of heating called bekindu' (literally 'to heat' or 'warm by a fire') which traditionally lasted from a month to forty-one days, its duration formerly reckoned by the use of a string tally (Sather 1988:165-166). ${ }^{32}$ During this time the mother heats herself by an open fire kept continuously burning inside the bilik and is treated with ginger and other heating agents so that her 'body is made warm' (ngangat ka tuboh). At the same time, members of the bilik-family observe a series of ritual restrictions (penti). These have a disjunctive effect, temporarily setting the family apart from the rest of the community whose members are not subject to the same restrictions. Similarly, heating itself places the mother and infant in a ritual status antithetical to other longhouse members.

For the mother, this status ends when she resumes river bathing at the penai', a 'cooling' act that marks her resumption of normal longhouse life. 'Heating' and 'bathing' are ritually antithetical categories, and before the mother resumes ordinary river bathing, she is first given a steambath (betangas) inside a mat enclosure at the tempuan bilik in which she is steamed with an infusion of medicinal leaves meant to induce heavy sweating (Sather 1988:166). 'Steaming' in this context can be interpreted as a mediating act between 'heating' and 'bathing'. For the infant, on the other hand, its first bath at the penai' is made the focus of a longhouse gawa' rite. This rite, the most elaborate of the series surrounding birth, gives social and ritual recognition to the infant's entry into 
the longhouse community. Following its first bathing, mother and child undergo a secondary bathing rite on the longhouse gallery marking their ritual incorporation. The movement represented is thus from seclusion to incorporation, from heating to cooling.

What is significant here is that this series of rites is enacted as an ordered movement through the longhouse itself: beginning in the relative security of the bilik apartment; moving outward to the open-air veranda, the zone of the house most removed from the bilik; then journeying in ritual procession from the gallery to the river bathing-place, at the outer threshold of the longhouse, and back again; and ending in a rite of incorporation on the communal gallery. This movement gives cultural construction to the infant's entry into the social and cosmological world - an entry signalled, at its beginning and end, by a fundamental ritual polarity: heating and bathing (or cooling). This polarity recurs at other life transitions as well, including death, and is an integral part of the rites that preserve the longhouse as a ritual entity, symbolized especially by its hearths and posts - the one a source of heat, the other of cooling.

Shortly after birth, as soon as the severed umbilical cord has dropped off, the infant's confinement is temporarily interrupted and it undergoes a secondary birth, this time outside the bilik, in a brief rite called ngetup garam literally 'to taste salt'. During this rite, the infant is carried from the bilik to the open-air veranda. Here it is presented to the sky (langit) and to the daylight (hari), the latter epitomizing the visible, 'seen' dimensions of bodily reality. ${ }^{33}$ It is made to look up into the sky and so 'take cognizance of the day' (nengkadah hari). At the same time, a small bit of salt is placed in the infant's mouth to give its body 'taste' (tabar). The elder holding the child then pronounces an invocation presenting the infant to the gods (petara) and asking them to take the child into their care. Reflecting Iban notions of the dichotomous nature of experience the contrast between waking reality and the dream world of the soul - the principal gods invoked are Selampandai, the creator-god who, as a blacksmith, forges and shapes the child's visible body (tuboh) (and later repairs it should it receive physical injury), and Ini Inda who, as the shaman goddess, is the principal protective deity associated with the soul (semengat) and with the invisible plant counterpart $(a y u)$ that represents human life in its mortal aspect.

For the Iban, a child's introduction into ritual life is graduated. Thus ngetup garam signals the first enlargement of its relational field beyond the bilik. Through ngetup garam the infant is removed for the first time from the confines of the bilik apartment and is introduced to the basic temporal dimensions of the Iban visible world, to daylight and the orbiting sun, and, at the same time, its presence is made known to the gods into whose care it is placed. The principal gods invoked are those responsible for the main constituents of its newly created person: namely, its visible body and its unseen soul. Finally, the journey from 
the bilik to the tanju' and back to the bilik is seen by the Iban as a movement between areas of minimal and maximal spiritual danger, and back again, within the longhouse.

The main rites of birth conclude with the infant's ritual first bath (meri' anak mandi') at the longhouse bathing place. Ritual bathing gives recognition to the child's social persona within the community, while similarly locating it ritually in a beneficent relation with the spiritual forces believed to be present beyond its threshold. The rite opens at dawn with the preparation of three sets of offerings on the family's section of the longhouse gallery. When prepared, one set of offerings is carried into the bilik apartment. There it is presented to the family's guardian spirits $\left(t u a^{\prime}\right)$. The other two are carried to the river side where, as part of the bathing ritual, one is presented to the spirits of the water (antu $a i^{\prime}$ ), the other to the spirits of the forest (antu babas).

As soon as these preparations are completed, the bathing party assembles on the gallery and is formed into a procession. After making a complete circuit of the gallery, its pathway strewn with popped rice, the procession, bearing the child, descends the entry ladder and proceeds in file to the river bathing place accompanied by the music of drums and gongs. At the penai' the offerings to the water spirits are cast into the river. The chief ritual officiant then wades into the water. Standing in the river, he pronounces a complex invocation (sampi) in which he calls on the spirits of the water to form a parallel, unseen procession in the realms beyond the longhouse threshold. The spirits are described in his invocation as arriving at the penai' from both upriver and downriver, from the river's headwaters, its many branching streams, and from its mouth at the sea. Like human beings, the spirits, although unseen, inhabit 'this world' (dunya $\left.t u^{\prime}\right)$. The invocation is characteristically structured as a dialogue in which the officiant becomes a number of different characters, both seen and unseen (Sather 1988:178-180). At first he self-reflexively describes the purpose of the rites and the intent of his own actions. Then, as they assemble, he assumes the identity of the spirits. These include the spirits of turtles, crocodiles and river fish. The spirits, through this dialogue, announce their arrival in processional order. Speaking through the officiant, they describe the magical blessings and charms they have brought to distribute among the bathing party and declare their intention to look after the infant, preserving it particularly from drowning (see Sather 1988:175-180). The guardianship of the river spirits, established at first bathing, is believed to continue throughout an individual's lifetime. In the poem of lamentation following death, the souls of the dead leave the familiar world of the longhouse by way of its bathing place, travel by river to the Otherworld and pass the homes of their former spirit-guardians. As they come to each of these homes in turn, they release the spirits from guardianship and bid them farewell. Later, in rituals that involve the souls' return from the Otherworld, the souls again pass these homes just before they reach the penai' of the living. 
The spatial imagery thus locates the river spirits within the living world but beyond the boundaries of human society, its outer limits defined in this ritual construction by the penai'.

As the infant is bathed, a chicken is sacrificed and its blood is allowed to flow into the river. The final set of offerings is then presented to the spirits of the forest. If the infant is male, these are hung from a spear (sangkoh), if female, they are hung from a shed-stick (leletan); spears and shed-sticks symbolizing the pre-eminent gender roles of men and women: warfare and weaving (Sather 1988:182). As these offerings are being set out the procession reassembles and, bearing the infant, returns to the longhouse gallery. Here the mother and infant undergo a secondary bathing rite called betata', literally 'to drench' or 'sprinkle with water'. The mother and child are seated together on a gong, covered by a ritual pua' cloth, at their family's section of the upper gallery (ruai atas). Here they are individually touched with water by other longhouse members and the family's guests from neighbouring communities. Betata' thus dramatizes the end of the mother's and child's confinement and their ritual reintegration into the community.

In the series of rites that follows birth, beginning with bekindu' and ending with betata', each rite makes use of a different socially demarcated area of the longhouse and its surroundings. As a result, the series as a whole is constituted as an ordered movement through the longhouse community at large. This movement ritually effects the progressive engagement of the newborn infant in an expanding series of social and ritual relationships - moving outward from the bilik to the longhouse and beyond to the larger river system that encompasses them both - and from confinement within the spiritually secure bilik apartment to location within an all-embracing, but increasingly dangerous cosmological order. Spiritual danger is spatialized and through the ritual organization of the longhouse, this danger is progressively confronted as the infant journeys through the community, becoming in the end a source of efficacy and spiritual protection. Finally, these journeys are always, like the internal ordering of the longhouse itself, bidirectional, returning to the source from which they began. Thus they move from inside to outside the longhouse, to its veranda and river bathing place, then back inside again, first to the bilik, then to the communal gallery; hence, not upriver and downriver but along its opposite, life-symbolizing east-west coordinates.

\section{Rites of Death}

In death the heating - bathing polarity is reversed. Immediately following death the body is bathed. This takes place, not at the threshold of the longhouse, but at its very centre on the liminal tempuan zone within the bilik. The floor of the tempuan bilik is especially slatted to allow bathing water to flow through it. Aside from containing the hearth, the tempuan bilik is also the location of the 
family's water gourds and it is here, where the water gourds are, or were traditionally, stored that the dead are bathed. ${ }^{34}$ After the body is bathed and dressed and three dots of turmeric are painted on its forehead, it is carried from the bilik onto the gallery. As it is carried through the bilik doorway, family members cast rice grain over it, signifying the separation of the dead from the family's cycle of work, ritual and commensality associated with rice cultivation. The grain represents the dead person's 'share' of the family's rice equivalent to his/her contribution to this cycle. The body is then placed on the lower gallery inside a rectangular enclosure (sapat) made of ritual ikat cloth ( $p u a^{\prime} k u m b u^{\prime}$ ). This enclosure is said to shield the rest of the house from the 'heat' of the corpse. The top of the enclosure is similarly covered with a cloth (dinding langit) to shield the sky. An external hearth (bedilang) ${ }^{35}$ is lit and kept burning at the feet of the body on the tempuan passageway beside the enclosure. ${ }^{36}$ This fire is meant to keep the dead from becoming 'cold' (chelap) ${ }^{37}$ and is carried by the burial party to the cemetery and extinguished only after the body is buried.

The body remains inside the sapat until it is buried. The initial period of mourning vigil, until the conclusion of burial, is called rabat. Burial takes place shortly before dawn and, throughout the night that precedes it, a female dirge singer (tukang sabak) sits beside the body and sings the poem of lamentation (sabak). As she sings, her soul accompanies the soul of the dead on its journey to the Otherworld. The words of her lamentation thus relate the experiences of this soul journey. In these experiences, the route of travel is depicted from this world to the Otherworld of the dead. It begins at the family hearth, with the soul first taking leave of the hearth frame. It then moves through the bilik apartment to the tempuan passage, and down the passageway to the entry ladder. Thus, its route of travel begins with the familiar landscape of the longhouse interior. In this sense, the lamentation stresses the continuity between this world and the next. The route the soul follows is identical to that later taken by the body as it is removed from the longhouse and carried to the cemetery. But what is significant here is that the words of the lamentation describe the unseen dimensions of this otherwise familiar setting. The soul enters into dialogue with the various features of the longhouse which now appear to the soul in spirit form. Some of these features are transfigured and perceived very differently from their everyday shapes. Thus, for example, the longhouse entry ladder now appears, in some versions of the sabak, as a crocodile. In this form, as a guardian of the community's spiritual well-being, it announces its intention to prevent the soul from leaving for the Otherworld. Again, in some versions, the ladder tells the soul that the celestial shamans were invoked by the people of the house and that the ladder was spiritually waved with a fowl in order to prevent longhouse members from departing to the Otherworld, that is from dying (Uchibori 1978:186-187). The soul asks to be allowed to pass, promising that a trophy head will soon be carried into the longhouse by its warriors. And so the 
ladder relents. ${ }^{38}$ Similarly, when the soul reaches the cleared ground at the foot of the ladder (menalan), it finds a large tree growing there which it has never seen before. The souls of the dead, who have come to join its journey, tell the soul of the newly deceased that this tree is called Ranyai Padi (see Uchibori 1978:186-187). It is covered with valuable wealth, sacra and magical charms. These the soul collects to give to the living as departing gifts. Later, during the rituals of memorialization (Gawai Antu), the souls of the dead, as they return to the longhouse of the living, again collect valuables from the Ranyai Padi tree which they give to their living descendants. Finally, the soul reaches the longhouse bathing place. Here it bathes in sorrow, knowing that it does so for the last time. Thus, the ritual singing of the poem of lamentation transfigures the longhouse landscape, superimposing an unseen reality on this otherwise familiar setting of everyday social life.

This superimposition of an unseen reality upon the visible features of the longhouse is developed even further by Iban shamans, who manipulate this transformation in order to work upon the social and intrasubjective experiences of their patients. In shamanic rituals of healing (pelian), the same journey is frequently depicted, but the course of travel followed by the souls and spirits is even more fully articulated with the physical and symbolic features of the longhouse.

The soul of a patient who is seriously sick may be diagnosed as being absent from the body and journeying on its way to the Otherworld. While in trance, the shaman's soul goes in pursuit, following the same route as the errant soul. As Uchibori writes:

Usually the shaman claims to have caught the errant semengat [soul] at a particular point along the way. He may tell the attendant people that he has caught it, for example, at the foot of a gallery pillar. In the spiritual vision of the shaman, a gallery pillar in the longhouse structure is said to be seen as a nibong palm which stands by the path to the Land of the Dead (1978:208).

As in the poem of lamentation, the soul begins its journey at the family hearth. In a complex metaphor, the hearth is described as the Bukit Lebor Api, the 'Hill of Raging Fire'. ${ }^{39}$ The 'dog wall' separating the bilik from the ruai appears as a ridge, at the foot of which is a lake called Danau Alai. In the everyday landscape of the longhouse this 'lake' is represented by the section of the tempuan bilik floor where the dead are bathed. From this 'lake' a 'stream' or 'path' leads to the 'Violently Shutting Rock' (Batu Tekup Daup), which continually opens and closes, violently. This 'rock' is represented by the door of the bilik apartment. After leaving the bilik, the soul enters the main river or pathway running to the Otherworld of the dead. This river or pathway is represented by the tempuan passageway. The rice mortars standing along the tempuan are seen by the souls 
as boulders; the main pillars dividing the tempuan from the ruai as nibong palms; and the passageway itself is seen as a broad, well-worn path or as the reaches of the Mandai River of the dead.

The imagery of this superimposed landscape varies in detail between different shamans and dirge singers. According to Uchibori's informants (1978:213), no reputable shaman in the Skrang would pursue a soul past the 'Bridge of Fear' (Titi Rawan) most often represented in the longhouse setting by its entry ladder. But in the Paku, shamans regularly travel beyond this point into the Otherworld itself, as well as to Mount Rabong and to the lairs of spirits who have taken the souls of their patients captive.

As in the poem of lamentation sung over the dead, the longhouse becomes a stage, with mundane social space transfigured to represent the reality that the soul experiences in the course of its travels and encounters with other unseen beings. The more serious the patient's illness, the further the shaman's soul must travel into the Otherworld in pursuit. Generally, the middle of the gallery represents the intermediate zone between the world of the living and the world of the dead. The shaman regularly uses props to signify landmarks within this unseen terrain: mortars, for example, as mountains, and a swing hung from the tempuan passageway to emulate the flight of his soul from one realm to another. The passageway itself typically represents the Mandai River, while the 'Bridge of Fear', which divides the living from the dead, is represented by a wooden pestle laid across the top of two upturned mortars blocking the end of the tempuan. The entry ladder now becomes the Limban Waterfalls (Wong Limban), a prominent landmark in the Otherworld. In this imagery, the Limban River, flowing through a deep chasm, is spanned by the 'Bridge of Fear' ${ }^{40}$

The clearing at the foot of the entry ladder to the longhouse represents the midway point in the shaman's possible journeys into the Otherworld. At this stage, however, the longhouse of the living now represents the longhouse of the dead. Spatial progression still represents increasing proximity to the dead, but now the direction is reversed. Like the ordering of longhouse tiang pemun, this movement is bidirectional. But here the 'tip', represented by the 'tip' of the longhouse (that is, the foot of the entry ladder), is reversed, becoming, not the destination of this movement, but its midpoint in a mirror-inverted journey back to its original starting point. Thus the shaman re-enters the longhouse and his rituals move back toward the bilik of his patient, now representing the Otherworld bilik in which the errant soul has taken final refuge. The final limit of the shaman's journey is thus marked by his entry into his patient's bilik apartment. The starting point of his journey thus becomes, in the inverted Otherworld of the dead, its destination. There inside the bilik, where the shaman began his pelian, he snatches the straying soul and carries it back to the house of the living. This final journey, from dead 'source' to living 'source', from the 
centre of the Otherworld to the centre of the living world, is represented by the shaman's physical passage through the apartment doorway, across the liminal tempuan passageway, from the bilik apartment to the longhouse gallery. ${ }^{41}$

Returning now to the rituals of death, following the singing of the poem of lamentation (nyabak), the body of the dead is carried from the longhouse and taken to the cemetery for burial. The route taken follows that of the soul as depicted in the sabak. In removing the body, upriver-downriver directions are observed. Thus the body, which is removed headfirst, is never carried past the central tiang pemun, but is removed by either the upriver or downriver entry ladder, depending on the location of the deceased's apartment relative to that of the pun rumah. In contrast, the body of a shaman is removed by way of the tanju'. In the cemetery, the latter is buried with its head upriver, in contrast to the ordinary dead who are buried with the head downriver. The difference reflects the different journey taken by the shaman's soul which, in death, is believed to travel to a separate Otherworld of the dead identified, not with the Mandai River, but with Mount Rabong at the juncture of 'this world' (dunya $\left.t u^{\prime}\right)$ and the sky (langit). Here the souls of former shamans, together with the shaman god, the brother of Ini Inda, and the spirits of celestial shamans, are thought by some to tend the plant images of the living (Sather 1993).

Following burial, during the initial mourning period called pana, a small hut (langkau) is erected between the river bathing place and the longhouse. Here food offerings are made each evening and in front of the hut a fire (api) is kept burning each night of pana, in an observance called tungkun api. The location of this hut and vigil-fire is called the palan tungkun api, 'the tungkun api resting-place' (Figure 5). Here the soul of the dead is said to return to eat and warm itself by the fire, its shadowy presence often seen just beyond the edge of firelight. As with birth, heating again signals an important transition. Here it occurs, however, not inside the bilik as at birth, but, reflecting the marginal status of the newly dead, outside the longhouse altogether, in the liminal in-between zone between the penai' and the foot of the longhouse entry ladder (Sather 1990:29). Its location is said to prevent the dead from re-entering the house of the living, where their presence would pose a danger to the community. At the same time, the bilik of the deceased is subject to an inverted temporal order, as an extension of the Otherworld. Thus during the day the apartment windows or skylights are sealed and the interior is kept in total darkness; darkness representing 'daylight' in the Otherworld. No one in the community may work outside the longhouse, and on each night of pana an elderly woman, ideally the oldest still alive in the community, eats black rice in the bilik. This rice, called asi pana, represents white rice in the Otherworld (see Sandin 1980:35). After a final meal of asi pana, before the bilik's windows are reopened at dawn to readmit daylight, a chicken is sacrificed and its blood is smeared by the woman on the window frames. Thus, for the duration of initial mourning, the bilik is 
placed in a disjunctive state, with daylight and darkness inverted, mirroring the reversed order of the Otherworld. This state ends with the sacrifice of a chicken and, paralleling the rites of birth, the ritual reintroduction of the bilik to daylight.

In addition to a body and soul, every living person is also constituted of a plant image ( $a y u$ ). This image is commonly likened, in appearance, to a bamboo or banana plant, and, like it, is said to grow as a shoot from a common clump made up of the ayu of its other bilik-family members (see Freeman 1970:21; Gomes 1911:169; Sather 1993). The ayu thus grow in family clumps, separate from the body and soul, on, some say, the slopes of Mount Rabong in the shamanic Otherworld. $^{42}$ In illness, a person's ayu is said 'to wither' (layu'), or become overgrown, and in death, 'to die' (perai). Thus in healing rituals, shamans often travel to Mount Rabong to 'weed' or 'fence around' a patient's ayu, ritually emulating these actions on the longhouse gallery. In death, a person's dead ayu must be severed (serara') from his or her family clump in order to safeguard the health and spiritual well-being of the surviving family members. Thus, sometime after pana and following ngetas ulit, the conclusion of formal mourning, a shaman is usually engaged to cut away the dead ayu of the deceased (Sandin 1980:33-38). This is particularly so if family members fall ill or are visited by the dead in dreams. The rite of cutting away the ayu is called beserara' bunga, literally 'to sever the flowers', and is performed on the longhouse gallery with the shaman's audience seated facing him along the panggau. The ayu is represented by a bamboo shoot or by the branch of a flowering plant, such as bunga telasih or emperawan, which is placed at centre stage, in front of the shaman on the patient's ruai. Here the shaman carefully cuts away a small piece of the outer sheath of the bamboo or part of the flowering branch. At the conclusion of the rite, the spirit of the dead is believed to appear beneath the tempuan passageway. Here the shaman presents it with a sacrifice and special offerings prepared by its bereaved family; these, together with its severed plant image, are then cast beneath the tempuan floor. The shaman concludes by placing the longhouse entrance under temporary taboo and by hanging a ritual pua' kumbu' cloth over the doorway of the deceased's bilik as a ritual barrier (pelepa'), thus completing the family's separation from the dead and reconstituting its ritual integrity. 


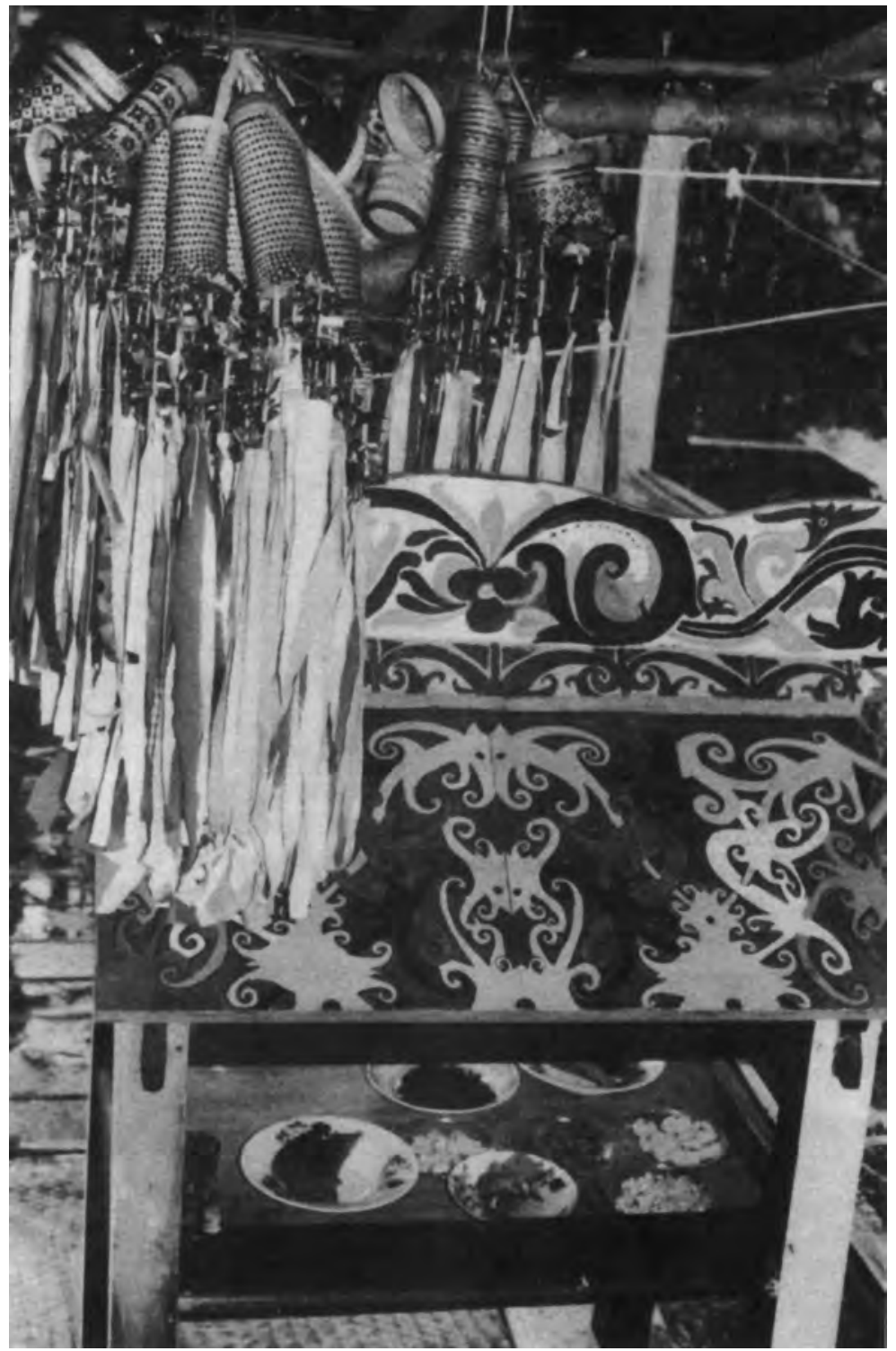

Figure 6. Tomb hut temporarily assembled on the veranda with offerings (below) and garong baskets hanging above it (Gawai Antu)

\section{The Gawai Antu}

The final secondary rites of the dead are the most complex of all. These rites, called the Gawai Antu, constitute major memorialization rituals and are ideally performed by each longhouse roughly once in every generation. Requiring several years of preparation, they memorialize all of the community's dead (orang ke perai) whose deaths occurred since the last Gawai was performed by the 
longhouse. The head of the bilik having the oldest dead acts as the 'Gawai elder' (tuai gawai). The Gawai Antu feasts the dead and completes their final transformation into spirits (merantu). This transformation is effected primarily by erecting, at the conclusion of the Gawai, tomb huts (sungkup) over the graves of the dead. These elaborately carved huts are made of ironwood and are equipped with miniature furnishings and garong baskets, the latter symbolizing the personal achievements of each individual dead (see Figure 6). In the Otherworld these huts represent full-size longhouses or, in totality, the parts of a single longhouse. The Gawai Antu thus establishes the dead in a longhouse of their own, thereby providing them with the means for a self-sufficient existence independent of the world of the living. For this reason, the Gawai is sometimes described by the bards as a rite of berumah (house construction). In this sense, the final rites of death are, significantly, house building rites. But unlike ordinary berumah, construction takes place, not in the visible world, but in the Otherworld of the dead, as the sungkup, at the conclusion of the Gawai, are reassembled in the cemetery, ritually separated and physically removed from the world of the living.

At its beginning and end, then, the main rites of Gawai Antu are bracketed by major stages of ritual house building. The Gawai opens with the gawai beban ramu, the 'ritual fashioning (ban) of construction materials (ramu)'. This is followed by ngeretok, the preparation of the parts of the sungkup huts, which are then carried from the forest and assembled by each family for temporary display on its tanju'. ${ }^{43}$ Finally, immediately following the main Gawai rituals, the sungkup are removed from the longhouse and carried to the cemetery where they are reassembled, away from the longhouse, over the graves of the dead.

On the day that precedes ngeretok - the preparation of the parts of the sungkup - families repair or replace their panggau platform and make ready their gallery to receive guests. ${ }^{44}$ In the late afternoon, the women begin to soak glutinous rice in the river, while the men construct the bamboo rugan altars in which each family feeds its dead. These are attached to the passageway pillar representing the family's tiang pemun (see Figure 7). This feeding begins at dusk on the evening prior to ngeretok and continues each night until the conclusion of the Gawai. At dusk, the first welcoming of the spirits of the dead (ngalu antu) is performed on the longhouse gallery. From now until the end of Gawai Antu, at dusk and at dawn, the spirits are welcomed and seen off, as they arrive in the world of the living and temporarily depart again. The Gawai emphasizes the complementarity of male and female roles, as on the following day when the men perform ngeretok, fashioning the sungkup huts, and the women plait the ritual garong baskets. The work of plaiting is called nganyam and is performed by the women inside the bilik apartments, while the men work on the upper gallery. Both these tasks are generally completed in a single day. Afterwards, several days of preparation elapse before the main Gawai rites resume. 


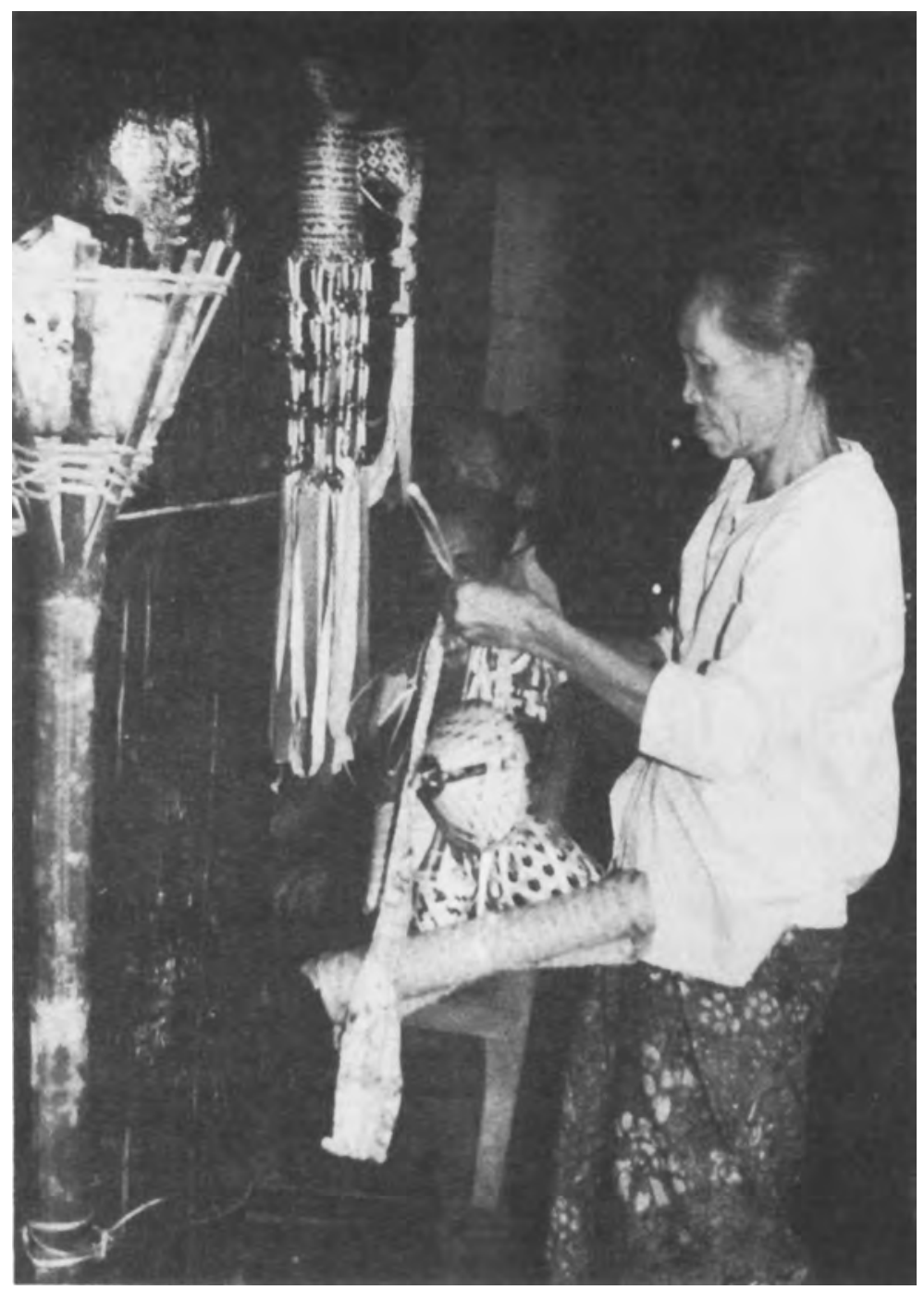

Figure 7. On the tempuan passageway during Gawai Antu: the rugan altar on the left; at the top a decorated garong basket with a smaller gadai (representing a slave attendant); and a woman hanging the furnishing of a newly constructed bilik of the dead

Kindred (kaban) generally arrive the day before the start of the Gawai proper in order to assist the host families with preparations. They bring with them fowls, eggs, fruit and garden produce. Beginning soon after dawn on the first day of Gawai Antu, guests (pengabang) begin to arrive. After bathing at the penai', they are ceremonially welcomed into the house. Among the first to be received are the principal warriors who will later drink the $a i^{\prime}$ buloh, the main ritual rice wine served from the garong containers plaited by the women. They 
are followed by a second group of warriors who will later drink the ai' timang jalong wine which is carried by the bards as they sing (nimang) the Gawai invocation. The welcoming of guests continues throughout much of the day. The principal guests comprise the house's cofeasting allies (sapemakai); they generally arrive and are received in groups, as longhouse communities. ${ }^{45}$ At dusk no further guests may be received. Instead, the hosts and guests combine to welcome the gods, spirit-heroes and spirits of the dead. After the latter have been welcomed and feasted with offerings, hosts and guests sit down to the first of a series of feasts consumed in emulation of their spiritual visitors.

During the performance of the Gawai Antu, the total panoply of intersecting social and cosmological categories comes into play and is given formal expression through the ritual organization of the longhouse itself. In everyday life these categories remain largely unmarked. Thus the Gawai makes explicit the basic categories of Iban social life: gender, age, bilik-family, longhouse, kindred and so on. The basic order of Gawai seating, for example, gives formal arrangement to gender and age categories. Adult and elderly male guests are seated along the raised panggau, while their male hosts sit facing them along the division between the upper and lower gallery. Married women sit either behind them, on the lower gallery, or remain inside the bilik where they receive and entertain women guests from other longhouses. While in everyday life these different areas of the house are used by both sexes, and by individuals of all ages, in terms of their ritual signification they are made, in this ritual ordering of space, to constitute these basic social distinctions. Thus the bilik is associated with women; the ruai with men; the upper sections of the house with men, seniority and age; the lower sections with women, juniority and the young. The transition from domestic to public space thus becomes a transition from women's to men's space, and from the bilik-family to the longhouse and its co-feasting allies. When food is served, the same distinctions are made. Young women cook at the hearths inside the tempuan section of the family apartment, older women eat in the main bilik, while young men carry food in and out of the bilik. Older men, both hosts and kindred, eat on the ruai, while the most senior male guests are served at the raised panggau. Thus, the relationship of domestic space to public space is like that of women to men, lower to upper, family to longhouse, young to old, hosts to guests, and so on. At times, however, in the course of ritual performance, these relationships are altered or inverted. During ritual processions, for example, gender and age distinctions are partially overridden, while other distinctions, such as those between hosts and guests or between ritual officiants and audience, are expressed instead. At other times formal gender arrangements are reversed, with men and women changing places. This occurs, for example, during the Gawai Antu following the invocation of the dead and signifies the state of inversion that distinguishes the Otherworld from the realm of the living. 
The ritual organization of longhouse space also underscores distinctions between the living and the dead and between human beings, the gods, spirit-heroes and spirits of the dead. After the human guests have arrived and been welcomed with rice wine at each family's section of the tempuan, they are shown to their hosts' ruai, where the male guests are eventually 'arranged in order' (bedigir) along their hosts' panggau. At dusk, the gods (petara) and returning spirits of the dead (antu sebayan) are invoked by the bards and welcomed to the house by the Gawai hosts and guests through a series of ritual processions (ngalu antu) that circle the upper and lower gallery (see Figure 8). But before the bards begin their invocation, the warriors who are to drink the ai' buloh wine prepare a pathway for the dead along the gallery floor (ngerandang jalai). Dancing along the ruai with drawn swords, they cut invisible 'undergrowth' and clear the way of spiritual obstructions (see Figure 9). After this, the warriors who are to drink the $a i^{\prime}$ jalong wine, make the path prepared by the first group of warriors ritually secure by metaphorically 'fencing it with an invisible handrailing' (ngelalau). The arrival of the dead is anticipated in other ways as well. While living guests are welcomed into the longhouse by way of its upriver entrance, the dead are believed to come from downriver, retracing the route of their - original departure. Thus, before the spirits arrive, all the mats covering the gallery floor are taken up at the direction of the Gawai elder, reversed, and laid down again, so that their edges now overlap in the opposite downriver-to-upriver direction. This is said to prevent the spirits of the dead from 'tripping' as they walk along the gallery floor, their actions emulated by the processions of human guests. 


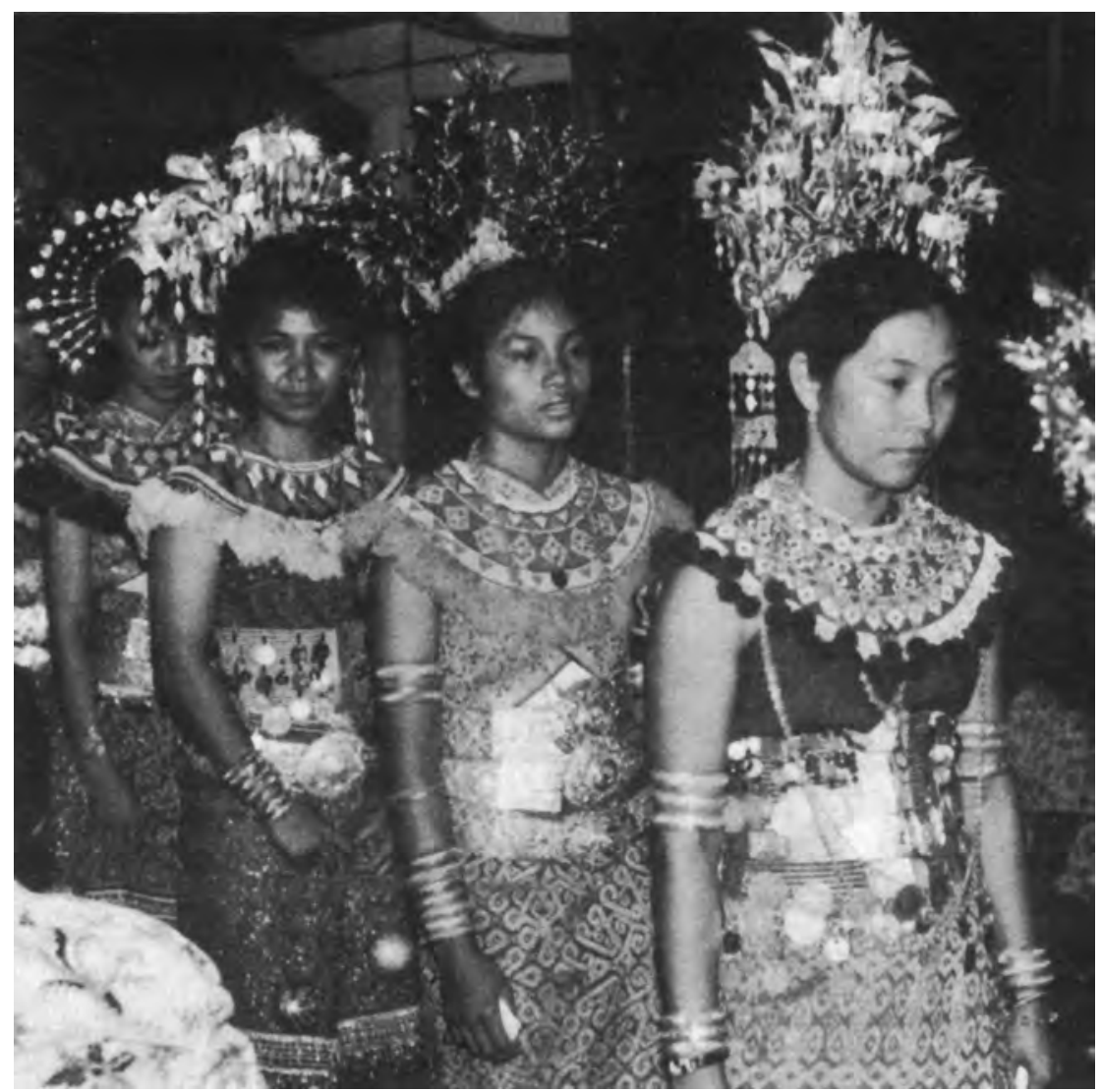

Figure 8. Maidens in procession 'to welcome the spirits' (ngalu antu), Ulu Bayor longhouse, Saribas

The spirits are led in procession by the gods and goddesses of the Otherworld, beginning with Raja Niram and his wife Ini Inan. They bring with them to the living world gifts to exchange with their former family members for food offerings. The bards begin their invocations inside the Gawai elder's bilik. They then move, in an important transition, onto the gallery where they sing the main timang invocations as they circumambulate the ruai floor, going from one end of the house to the other. Their movements at once emulate the journey of the dead and at the same time define the whole of the longhouse as a ritual space. As they sing they carry cupped in the palm of their right hand a bowl of ritual wine called the $a i^{\prime}$ jalong. The invocation they sing recounts the journey of the gods and spirits as they travel from the world of the dead (menoa orang mati) to the world of the living (menoa orang idup). In this journey, the spirits pass through a series of unseen realms, as in the poem of lamentation, except that now the direction of the journey is reversed. Prominent among these realms, and adjacent to the land of the dead, are the settlements of the spirits of various 
kinds of birds associated with death, including the Bubut (the coucal or crow pheasant) who watches over the Bridge of Fear dividing life and death. In time, they enter into the longhouse menoa. Here they pass ancient house sites and former farmlands, which the spirits of the dead recall from former times when they were still alive. They finally reach the river-landing threshold between this world and the world of the dead. From here they travel by boat. Journeying along the river, they pass the spirit realms of the tortoises, crocodiles, fish and other river spirits who were invoked when the newborn infant received its ritual first bath. After passing these realms, they reach the bathing place of the longhouse holding the Gawai. Here they bathe and are received in a ceremonial procession. They are welcomed with food offerings, and, as they arrive inside the house, the men and women of the longhouse sing songs (berenong), in the form of a conversational exchange between the living and the dead, to entertain them. The spirits are also welcomed with a series of cockfights held on the gallery floor. Here cocks belonging to the visitors and hosts are pitted against one another. Those of the visitors represent the cocks of the dead and those of the hosts, the cocks of the living. In these contests, the cocks of the dead always 'lose' to those of the living, no matter what the actual outcome. 
Inside Austronesian Houses

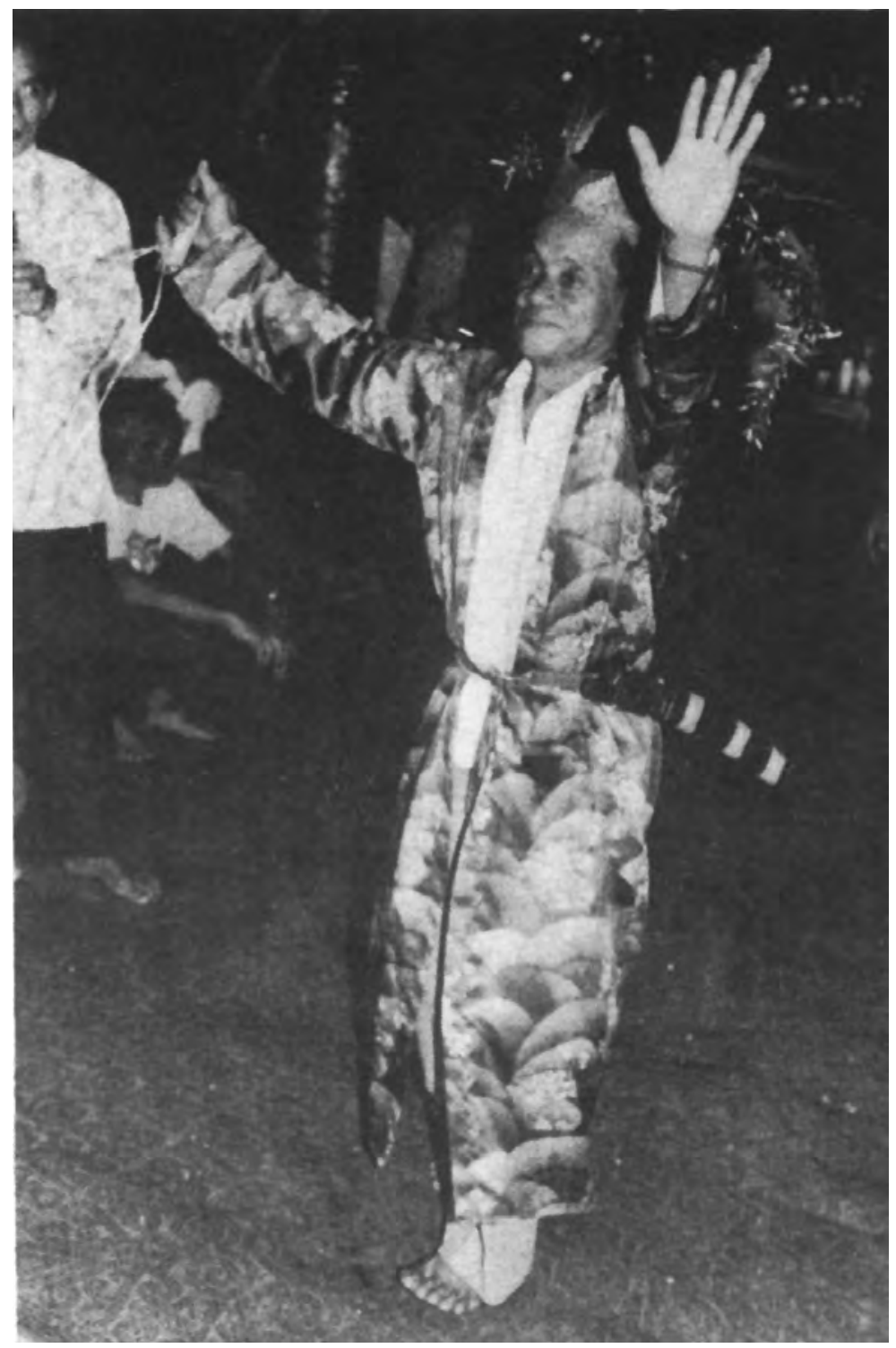

Figure 9. Ngerandang jalai; a warrior cutting a path for the dead along the ruai gallery at the start of Gawai Antu 


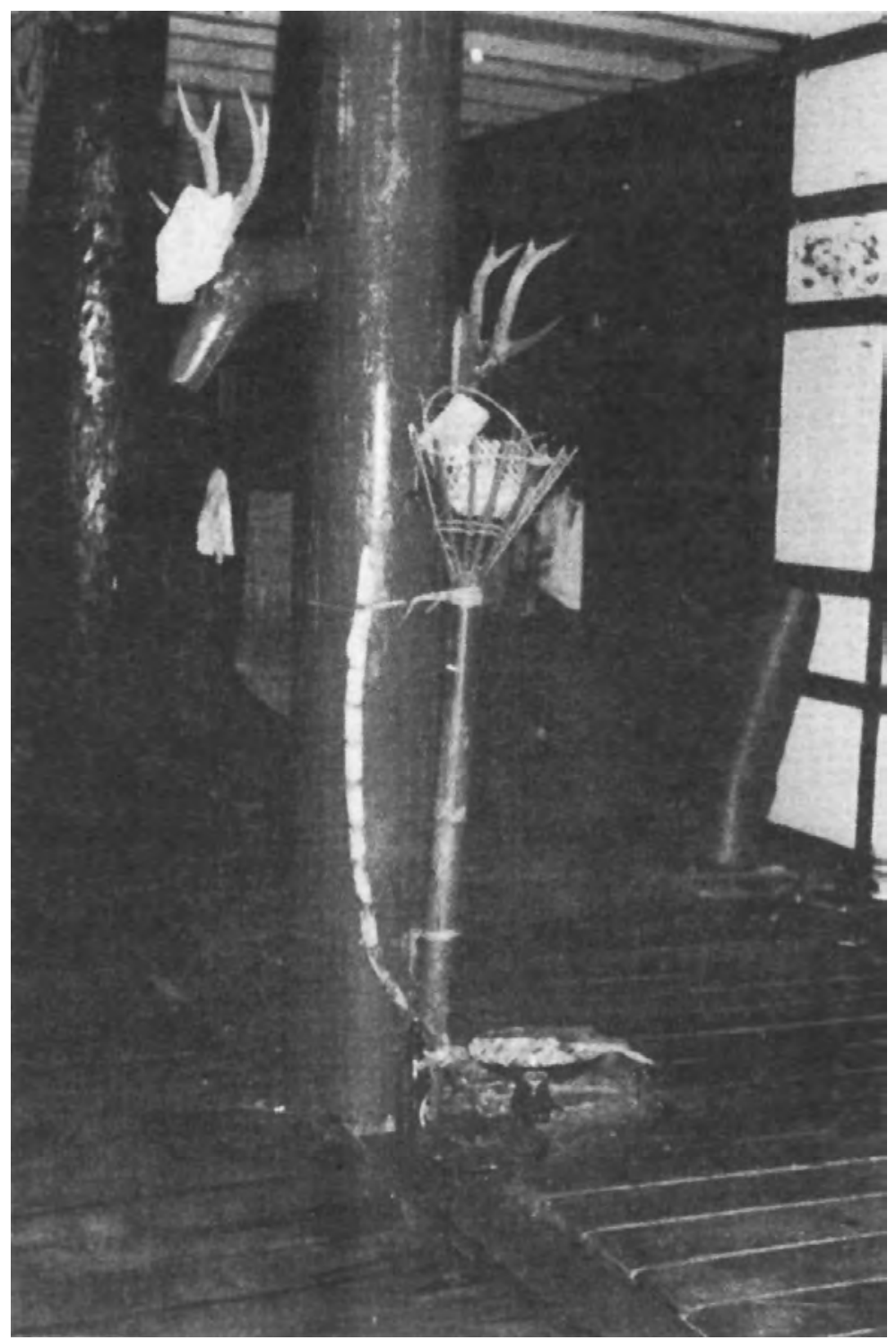

Figure 10. The rugan attached to the tempuan pillar, with a hearth at its base

From dusk, when they are first invoked, and throughout the night that follows, the gallery itself is believed to be thronged with unseen visitors. In their processions, feasting and drinking, cockfighting, and other actions, the hosts and guests play the part of these visitors: the spirits of the dead, gods, and spirit-heroes and heroines. ${ }^{46}$ During the night, older men in the house may sleep on the gallery in order to share the same space with the dead. Yet distinctions between the living and the dead are maintained; the spirits of the family dead are received, not inside the bilik, but on the tempuan passageway. 
Here they are fed in the rugan altar, which, together with a stalk of sugarcane, is attached to the tempuan pillar representing the tiang pemun (see Figure 10). In addition to being given special foods unique to the dead, such as smoked belau fish and keli eels, the family lights a fire each evening at the base of the rugan so that the family's spirits may warm themselves.

As the end of the night approaches, the bards finish their timang songs and the second group of warriors who are to drink the $a i^{\prime}$ jalong wine are arranged in a row along the upper gallery with the women who will serve them seated facing them (see Figure 11). A few other guests, as a special honour, are invited to sit beside the warriors. Only men who have received dream instructions or who have killed in war (bedengah) may drink these ritual wines. As the men and women are seated, the bards come forward, each carrying a cup of wine. As they approach, they sing praise songs which relate how the Otherworld goddesses Ini Inan and Endu Dara Rambai Geruda are searching for brave warriors to drink the sacred wine. The bards then place a cup in front of each woman, who, representing a goddess, serves it to the warrior facing her. Before he drinks, the warrior first 'clears' the wine with the tip of his sword. Then, after he drinks, he gives a loud war shout. After this, the leader of the first group of warriors who are to drink the ai' buloh wine goes from one family's section of the tempuan to the next and dismantles the rugan altars and cast them under the tempuan floor. This is a moment of great poignancy, for it marks the severing for each bilik family of its conjunction with its dead for another generation. The next time the Gawai is held some of its current members are likely to be among the newly dead being memorialized. 


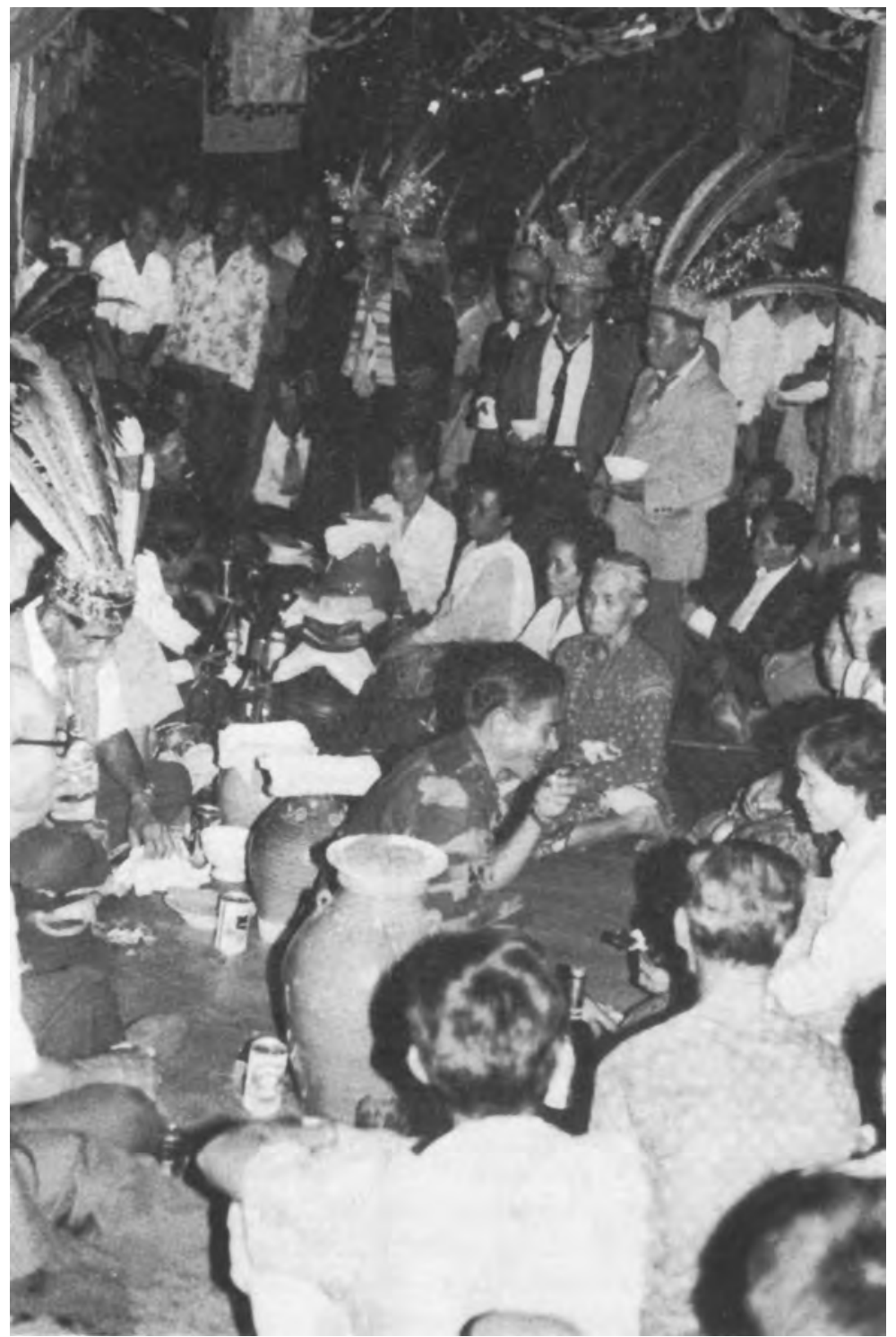

Figure 11. Women serving the warriors ai' jalong during the Gawai Antu; behind them a group of bards with two still holding bowls of wine

Following the 'casting away of the rugan' (muai rugan), the climax of the Gawai occurs at dawn when the principal warriors drink the ai' buloh (or $a i^{\prime}$ garong) wine from bamboo tubes inserted in the plaited garong baskets. One basket is woven for each individual dead, but only those of adults hold wine tubes. They are served by the previous group of warriors in a mock combat. Only men of singular prowess can drink the $a i^{\prime}$ buloh. Many Saribas bards equate this wine with the $a i^{\prime}$ limban, the lymphatic fluids that flow from a decomposing 
corpse. But in the dichotomous seen/unseen imagery of the Iban, the Limban is also the major river of the Otherworld that separates this world from the next. During the Gawai Antu the Limban River is verbally identified with the tempuan passageway, while the Bridge of Fear that spans it - linking the living and dead — is signified by a pestle laying width-wise across it.

Here, then, longhouse space is transformed by Iban rituals of birth and death from the familiar mundane setting of everyday social life to a symbolically organized landscape, displaying basic social distinctions and mirroring a series of superimposed realities, both seen and unseen. Everyday social space is merged with unseen 'spiritual' space and through the ritual organization of the longhouse, the order underlying Iban social experience is given explicit form, while at the same time this order is transformed to conjoin the seen realities of everyday social life with the invisible realities of the soul, spirits and the gods. ${ }^{47}$

\section{Conclusion}

In this essay I have examined the ways in which the Iban longhouse is constructed, not so much as a physical form, but as a ritually-constituted reality. In doing so, I have looked in particular at rites which focus on the longhouse itself, its physical construction and persistence as a ritual community, and at those which mark, in a parallel fashion, an individual's passage through the longhouse community from birth to death, as this passage is represented by a series of longhouse journeys. The principal argument I advance here is that the order-making power of ritual correlates spatial and architectural features of the longhouse in a series of meaningful ways. To these features ritual adds 'rules of performance' by which they are combined, in a convincing manner, to form multiple orders of meaning. Working mainly through images of landscape and motion, these 'orders' reveal at once the basic structures of everyday social life and at the same time a series of superimposed realities, positioning the longhouse cosmically as a threshold between the worlds of the living and the dead, the human world and the worlds of the gods, spirits and souls.

Robert Barrett (1993), in a penetrating analysis of Iban shamanism, develops a similar argument. Thus he maintains that

[t]hrough the processual organization of longhouse space within ritual, the major structures of Iban society are revealed. Gender and age categories become distinct. The relationship between the bilik-family and the longhouse community is defined and redefined, first as a discrete group, then opened out and articulated with the longhouse, then circumscribed as a discrete entity again. Within the reality of the pelian, the manang [shaman] brings into relief the major categories of being within the Iban cosmos - the living, the spirits, the dead and gods and their various habitats (Barrett 1993:255). 
Thus, the organization of longhouse space, through ritual performance, procession and invocation, interrelates its architectural and areal features to display a series of microcosmic images of the Iban social and ritual universe. These images are represented primarily as pathways of biographical transition or as arenas of communication and journeying, in which the welfare of the longhouse, its inhabitants and their domain is continually asserted and preserved, with ritual not only dramatizing but effecting transformations in these relationships and so, in an ongoing way, in the lived experience of its participants.

Today a growing body of ethnographic studies treat the symbolic organization of built forms — the 'house' in particular (Barnes 1974; Bourdieu 1970; Cunningham 1964; Ellen 1986; Forth 1981; Fox 1980; Kana 1980; Waterson 1988, 1990). 'Because', as Ellen (1986) observes, 'so many of our social interactions take place in houses', the house constitutes a 'culturally significant space of the highest order' (p.3). While some studies have sought

the 'rules governing' the structure of space [itself] ... Most have simply sought to find a symbolic concordance between the house and other collective representations ... not necessarily implying microcosmic status for the house, but merely stressing its fit with more general categories and principles (Ellen 1986:4).

While acknowledging the usefulness of beginning an analysis of local representations with the house, Ellen argues against any assumption that the house enjoys priority in this regard, or that 'house symbolism is a puzzle' to which there is 'one and only [one] solution' (p.4). Basically, Ellen's argument is that the house cannot be isolated from other symbolic domains, or from differing 'levels' of meaning; 'that symbolic worlds', by their nature, 'can only be understood in terms of other symbols' (p.1). Therefore, in analysing the house 'we are dealing with interpenetrating and non-reducible levels of meaning', such that the house, rather than representing a single fixed order located at the centre of an independent symbolic universe, 'depends for its imagery on other symbolic microcosms' (p.5). Without endorsing Ellen's critique of structural studies of the house, the point he derives from this argument is, I think, well taken, namely that

$[\mathrm{w}]$ hat is ... interesting about houses is that they not merely express order, but that the orders [they express] may be of various kinds, understood in different ways [by] different people on different occasions (1986:4).

I would go further and argue that what is more interesting yet, is not simply that the house may express different 'orders', but that these orders are actively created, contested and rendered convincing in the ongoing processes of social 
life, including, importantly, those of ritual. It is by exploring these processes, I would add, that detailed ethnographic analysis of the house has most to offer.

In this paper I have looked at a few of these ordering processes as they apply to the Iban longhouse. Not only does the ritual organization of longhouse space express multiple 'orders', but, through longhouse and individual life-passage rites, these orders are constantly created and re-created by the participants themselves. As Victor Turner (1967:20) reminds us, rituals and the symbols they employ are 'essentially involved in social process'. Thus rituals help establish and sustain the longhouse as a social community. In doing so, they make explicit the part-whole relationships that exist between its structural elements, expressing these relationships in metaphors of time and process, which not only 'reflect' their existence, but are themselves constitutive of the very social realities they represent.

Ritual, for the Iban, not only 'enacts' but is believed to have actual consequences. Thus, among other things, ritual effects transitions and changes of status, giving cultural construction to what Rosaldo (1980:109) calls the 'articulation of structure and event', the conjunction of social relationships with personal history and experience. Longhouse rituals not only display social categories and relationships, but also mark the entry of individuals into, and their final disengagement from, the community as experienced events in the social life of the longhouse. Consequently the ritual organization of longhouse space supplies coordinates of motion rather than stasis; it forms a terrain, at once social and symbolic, that each person traverses, again and again, in a series of life-journeys, rather than a fixed, physical matrix into which social life itself must be fitted or made to conform. In this regard, the longhouse represents, for the Iban, the setting of biographical events, scenes of vital activity, both seen and unseen, rather than an inert physical structure.

Not only does ritual performance generate multiple 'orders' of meaning, but in doing so, it renders any one of these orders problematic. In this sense, ritual is also involved in the creative work of transforming the lived experiences of its participants. As Barrett (1993) stresses, ritual not so much enacts a 'text' as creates meaning by the interaction of its performers and the structure of their performance itself. Meaning, including the meaning of ritual, is thus open to continual reinterpretation. As Barrett notes, in writing of Iban curing ritual,

[w] hile it is important to see ritual as a context in which the performance of cultural experts transforms patient and audience, ... it is just as important to see the patient, his suffering and his disturbed social relations, as a social arena within which cultural experts can define and transform the nature of ritual, cosmology, and the basic parameters of lived experience. Through discourse on performance, cultural members articulate ... theories of appearances and their relation to the multiple 
realities defined by their culture ... [As a consequence] the relationship between appearances and things is made problematic. Phenomena are demonstrated to be expressions of alternative possible noumena, depending on the reality within which they are defined (Barrett 1993:272)

A final point is that the representation of the longhouse that emerges from ritual differs in important respects from the one most commonly portrayed in the ethnographic literature. For example, the Iban longhouse is described by Freeman (1970:104) as 'a free and conditional association of corporate family groups'. Longhouse membership 'does not deprive a bilik-family of its essential autonomy' (p. 129); instead, Freeman maintains,

[a] long-house consists of a federation of independent families ... [which] must be conceived of, not as a unified group, but rather as a territorial aggregation of discrete units; not as a communal pavilion, but as a street of privately owned, semi-detached houses. Within the long-house all bilek-families are at jural parity ... [A] long-house is without formal hierarchical, or hegemonic organization (1970:129).

Reflecting its federated nature, individual families may freely join any longhouse in which they have kinfolk, their dissociation from one community and acceptance by another being a relatively simple matter.

Such an account, while not inaccurate, presents, nevertheless, only a partial view of the Iban longhouse. ${ }^{48}$ While Freeman stresses its individualistic, non-hierachical and competitive elements, ritual clearly reveals another side of longhouse sociality. As Freeman (1981) rightly insists, Iban society is notably lacking in institutions of stratification, hereditary inequality and political hegemony, yet the ritual constitution of the longhouse clearly entails relations of 'hierarchy' in the Dumontian sense of 'encompassment' of opposed categories, or more accurately, of 'precedence' (Fox 1990), which override elements of autonomy and individualism. The basic structural elements of Iban society are located ritually in an ordered series of part-whole relationships, arrayed in turn in a linear, or, more accurately, a bilateral reversible order of precedence, whose relations are defined primarily by orientational notions and by botanic and temporalizing metaphors of 'source' and 'tip'. In maintaining the harmony of the longhouse as a ritual entity, each individual family is subordinated to collective goals, expressed primarily through its hearths and posts, while ritual preserves the relationship between these structural elements, each encompassed by a larger totality: from the bilik-family, through the longhouse, to the wider river region. Freeman (1970) has stressed the special status of ritual in this regard and in discussing the 'corporateness' of the longhouse, rightly notes that 'inasmuch as it ... exist[s] it stems from ritual concepts, rather than from collective ownership of land or property' (p. 104). Yet the very notion of 'corporateness', 
and the proprietary terms in which it is defined, clearly privilege relations of physicality and so, I would stress, present us with only a partial view of the longhouse, at odds, as I have tried to show, with its indigenous representation.

\section{References}

Adelaar, K.A.

1985 Proto-Malayic. Alblasserdam: Offsetdrukkerij Kanters B.V.

Barrett, Robert

1993 Performance, effectiveness and the Iban Manang. In Robert Winzeler (ed.) The seen and the unseen: shamanism, mediumship and possession in Borneo (Borneo Research Council, Monograph Series No. 2), pp.231-275. Williamsburg, Virginia: Borneo Research Council.

Barnes, Robert

1974 Kedang: a study of the collective thought of an Eastern Indonesian people. Oxford: Clarendon Press.

Bourdieu, $\mathrm{P}$.

1970 The Berber house or the world reversed. In J. Pouillon and P. Maranda (eds) Echanges et communications: melanges offerts àClaude Lévi-Strauss àl'occasion de son 60ème anniversaire, Vol. 2. The Hague: Mouton.

Cunningham, Clark

1964 Order in the Atoni house. Bijdragen tot de Taal-, Land-en Volkenkunde 120:34-68.

Ellen, Roy

1986 Microcosm, macrocosm and the Nuaulu house: concerning the reductionist fallacy as applied to metaphorical levels. Bijdragen tot de Taal-, Landen Volkenkunde 142:1-30.

Fox, James J.

1980 Introduction. In James J. Fox (ed.) The flow of life: essays on Eastern Indonesia, pp.1-18. Cambridge, Mass.: Harvard University Press.

1990 Hierarchy and Precedence. Canberra: Comparative Austronesian Project (Working paper No. 3), Department of Anthropology, Research School of Pacific Studies, The Australian National University.

Freeman, Derek

1957 The family system of the Iban of Borneo. In Jack Goody (ed.) The developmental cycle in domestic groups (Cambridge Papers in Social Anthropology, No. 1), pp.15-52. Cambridge: Cambridge University Press. 
1960 The Iban of Western Borneo. In G.P. Murdock (ed.) Social structure in Southeast Asia, pp.65-87. Chicago: Quadrangle Books.

1961 On the concept of the kindred. Journal of the Royal Anthropological Institute 91:192-220.

1970 Report on the Iban. London: The Athlone Press.

1981 Some reflections on the nature of Iban society. Canberra: Department of Anthropology, Research School of Pacific Studies, The Australian National University.

Gomes, Edwin

1911 Seventeen years among the Sea Dyaks of Borneo. London: Seeley and Company.

Harrisson, Tom and Benedict Sandin

1966 Borneo writing boards. In Tom Harrisson (ed.) Borneo writing boards and related matters (Special Monograph No. 1). Sarawak Museum Journal 13:32-286.

Helliwell, Christine

1990 The ricefield and the hearth: social relations in a Borneo Dayak community. PhD thesis, The Australian National University, Canberra.

Heppell, Michael

1975 Iban social control: the infant and the adult. PhD thesis, The Australian National University, Canberra.

Hudson, A.B.

1970 A note on Selako: Malayic Dayak and Land Dayak languages in Western Borneo. Sarawak Museum Journal 18:301-318.

1977 Linguistic relations among Bornean peoples with special reference to Sarawak. Studies in Third World Societies 3:1-44.

Kana, N.L.

1980 The order and significance of the Savunese house. In James J. Fox (ed.) The flow of life: essays on Eastern Indonesia, pp.221-230. Cambridge: Harvard University Press.

Masing, James Jemut

1981 The coming of the gods: a study of invocatory chant of the Iban of the Baleh River Region of Sarawak. PhD thesis, The Australian National University, Canberra.

Pringle, Robert 
Inside Austronesian Houses

1970 Rajahs and rebels: the Ibans of Sarawak under Brooke rule, 1841-1941. London: Macmillan.

Richards, Anthony

1981 An Iban-English dictionary. Oxford: Clarendon Press.

Rosaldo, Renato

1980 Ilongot headhunting, 1883-1974: a study in society and history. Stanford: Stanford University Press.

Sandin, Benedict

1966 Tusun Pendiau (Iban). Kuching: Borneo Literature Bureau.

1967a Simpulang or Pulang Gana: the founder of Dayak agriculture. Sarawak Museum Journal 15(30-31):245-406.

1967b The Sea Dayaks of Borneo before white rajah rule. London: Macmillan.

1980 Iban adat and augury. Penang: Penerbit Universiti Sains Malaysia.

Sather, Clifford

1977a Introduction. In Benedict Sandin Gawai Burong: the chants and celebrations of the Iban bird festival, pp.vii-xvi. Penang: Penerbit Universiti Sains Malaysia.

1977b Nanchang Padi: symbolism of the Saribas Iban first rites of harvest. Journal of the Malaysian Branch of the Royal Asiatic Society 50(2):150-170.

1978 The malevolent koklir. Iban concepts of sexual peril and the dangers of childbirth. Bijdragen tot de Taal-, Land-en Volkenkunde 134:310-355.

1980 Introduction. In Benedict Sandin Iban adat and augury, pp.xi-xlv. Penang: Penerbit Universiti Sains Malaysia.

1985 Iban agricultural augury. Sarawak Museum Journal 34:1-35.

1988 Meri anak mandi': the ritual first bathing of Iban infants. Contributions to Southeast Asian Ethnography 7:157-187.

1990 Trees and tree tenure in Paku Iban society: the management of secondary forest resources in a long-established Iban community. Borneo Review $1: 16-40$.

1993 Shaman and fool: representations of the shaman in Iban comic fables. In Robert Winzeler (ed.) The seen and the unseen: shamanism, mediumship and possession in Borneo (Borneo Research Council Monograph Series No. 2), pp.277-318. Williamsburg, Virginia: Borneo Research Council.

n.d. 'All threads are white': Iban egalitarianism reconsidered. Forthcoming in James J. Fox and Clifford Sather (eds) Origins, ancestry and alliance.

Sutlive, Vinson 
1978 The Iban of Sarawak. Arlington Heights: AHM Publishing Corporation. Turner, Victor

1967 The forest of symbols. Ithaca, N.Y.: Cornell University Press.

Uchibori, Motomitsu

1978 The leaving of this transient world: a study of Iban eschatology and mortuary practices. PhD thesis, The Australian National University, Canberra.

Waterson, Roxana

1988 The house and the world: the symbolism of Sa'dan Toraja house carvings. RES 15:35-60.

1990 The living house: an anthropology of architecture in South-East Asia. Kuala Lumpur: Oxford University Press.

\section{Notes}

The fieldwork on which this paper is based was carried out at Kerangan Pinggai longhouse, Ulu Paku, Saribas, during university holidays, 1976-79, 1981-84, and 1988. The present essay had its beginnings in a paper presented at a session of the American Anthropological Association meetings, sponsored by the Borneo Research Council in 1988, on 'Rites of Passage'. An initial version of the present paper was read at a seminar on 'House and Household' conducted by the Comparative Austronesian Project, Department of Anthropology, Research School of Pacific Studies, The Australian National University in April 1989. I am grateful to those present on both occasions for their comments and criticisms and wish to thank in particular George Appell, Robert Barrett, Aletta Biersack, James Fox, Penelope Graham and Mark Mosko for their critical reading of earlier drafts of this essay.

1 Besides Iban, the Ibanic group of Malayic Dayak languages includes Mualang, Kantu', Bugau, Desa and Air Tabun (Hudson 1970:302-303).

2 Menoa refers to the territorial domain held and used by any distinct community, not only a longhouse, but also an entire river region. In fact, the term menoa may encompass a number of regions; thus the Sarawak Iban describe as their menoa lama', or old domain, the regions of the First and Second Divisions, including the Saribas, that were settled in the course of the first great Iban migrations into Sarawak some 300 to 350 years ago. The menoa rumah, or longhouse domain, consists ideally of the 'house, farms, gardens, fruit groves, cemetery, water, and all forest within half a day's journey', the use of which is 'only gained and maintained by much effort and danger and by proper rites to secure and preserve a ritual harmony of all within' (Richards 1981:215). For a discussion of the major features of the longhouse menoa, including its forests, fruit groves and immediate longhouse precinct, see Sather (1990).

3 Members of the Brooke family, the so-called 'White Rajahs', ruled Sarawak for a century (1841-1941) as an independent Raj under British protection (Pringle 1970). Following World War II, Sarawak was administered briefly as a British colony, gaining independence in 1963, as a State within the Federation of Malaysia.

4 The roles of tuai and pun may be, and sometimes are, combined. Thus the same person may be both the longhouse headman and the pun rumah. In the Paku, however, it is preferred that the two roles be played by different persons, primarily because the disputes and trouble cases that the headman hears 
on his family's section of the gallery are thought to jeopardize the central tiang pemun, potentially 'heating' it. The role of the pun rumah may, in addition, be combined with that of the tuai burong (longhouse augur). However, today in the Paku not all houses acknowledge an augur. Like the longhouse tuai and pun, the tuai bilik and pun bilik may also be, and much more often are, the same person. In addition, each community, for the duration of its annual farming year, selects at least one tuai umai (farming elder) to enforce its adat umai, the farming rules that regulate the behaviour of its members while they work their farms outside the longhouse.

5 These are the major initiating rites. Ngentak is preceded, however, by a brief ritual preparation of the site following its selection and confirmation by divination. This is called ngerembang (noun form rembang), literally, 'to tread down', 'clear a way' or 'make a pathway', and is performed by the owner-to-be of the central tiang pemun. During ngerembang the longhouse site is measured out, the location of its posts are fixed, and three offerings are made to the principal deities associated with the earth, Simpulang Gana and Raja Samarugah, one each at the middle and two ends of the site. Thus, in the process of reclaiming the site from forest, the basic constitution of the longhouse, as a 'cleared pathway' (ngerembang jalai) — with a centre and bilateral ends — is established through offerings and the ritual measuring out or 'treading down' of the site. Significantly, the longhouse is first conceptually realized in the mind of its pun rumah and marked out ritually as a 'cleared pathway', before it is actualized in a physical sense through the erection of its 'source posts'.

6 These objects include fruit of the apong palm (buah tamatu) representing a spirit repellant; favourable augury sticks (tambak burong) collected when the longhouse site was first chosen and the choice submitted to divination; salt (garam); skins of the langgir fruit used for bathing; a batu kuai, a translucent stone for cooling; and a branch of the mumban plant. The significance of mumban is discussed presently (see n.16).

7 In Iban oral genealogies (tusut) each generation is represented by a married pair (lakibini) rather than a single individual. Thus tusuts are characteristically recited in the form of 'A takes a husband (or wife) $\mathrm{B}$ and begets $\mathrm{C}$; $\mathrm{C}$ takes a wife (or husband) $\mathrm{D}$ and begets $\mathrm{E}$, etc. ( $A$ belaki diambi' $B$ beranak ka $C$; $C$ bebini ngambi' $D$ beranak $k a E$, etc.). This system of reckoning ascent accords with bilik affiliation, which is by marriage as well as by birth, and with the highly ramifying manner in which the Iban trace kindred relationships (Sather n.d.). The Paku River was first settled by the Iban some fourteen to fifteen generations ago, but genealogies of even greater depth are not uncommon (see Sandin 1967b:93-96).

8 The order of family apartments within the house is negotiated in an open meeting of longhouse members (aum) that precedes the start of house construction. Choice is restrained by a number of rules. Thus, for example, it is prohibited (mali) for a family to locate its bilik between the biliks of two siblings. This prohibition is called mali kepit, kepit meaning literally 'to squeeze'.

9 More abstractly, the rule is enda' tau' meraka' orang ke-dulu, 'it is prohibited to cross (or pass) in front of those who have gone first'. This rule is observed, for example, by the Iban when they encounter others while walking on footpaths or inside the longhouse. One must not walk, or cut in front of another person without apologizing. When he was small, my son often ran in and out of groups of people walking in file along paths, inviting humorous comments that he was behaving like a puppy (rather than a human being). Meraka' (or peraka') also means, more generally, 'to transgress' or 'disobey' (Richards 1981:275). The phrase orang ke-dulu is ordinarily used in this connection only for the pun rumah and the members of his or her bilik, and, in practice, precedence is strictly observed only in regard to 'crossing in front of' the pun rumah's central tiang pemun. This accords with the social recognition of precedence, in which only the central bilik has ritual priority, being associated with the initiation and ancestry of the house, while the lateral apartments, upriver and downriver, are essentially co-equal and without special ritual status associated with their location within the house.

10 Significant ritual fines are imposed on families that fail to install their hearths during pindah since their failure disturbs this ordered arrangement of precedence between family dapur.

11 Should another member of the longhouse become seriously ill or die, as a result of a bilik's neglect of its hearth, this constitutes a major longhouse offence and the guilty bilik is fined according to adat tungkal dapur (see Sandin 1980:12). Some say that offences against the adat dapur are punished by the antu dapur spirits.

12 Thirty-two of the thirty-three longhouses in the Paku are laid out along an upriver-downriver axis. The one exception, Bangkit Ijok, is built perpendicular to the main course of the Bangkit stream. Here 'downriver' and 'upriver' are replaced, respectively, by 'towards the river' (baroh, 'below') and 'away from the river' (atas, 'above').

13 There are occasional exceptions. Thus at Kerangan Pinggai, the upriver-downriver location of the tiang pemun is reversed. Nonetheless, the same order of precedence exists between its biliks. 
14 The Iban distinguish between puchok, the tip of an upstanding object, notably a tree, and ujong, the tip of one laying horizontally. Thus, when a living tree is felled, what was its puchok (tip) becomes its ujong. Only when, as a building timber, it is re-erected as a standing tiang does its 'tip' again become puchok. This distinction is associated with the major division of construction materials between tiang, upstanding elements with pun and puchok, and ramu, horizontal elements with pun and ujong. While the orientation of the tiang has already been discussed, that of the ramu is described below and summarized in Figure 4.

15 Thus Iban reverses the English association of a river's 'source' with its headwaters, associating it instead with its mouth (nanga).

16 Thus, the offerings include a branch of mumban, a small shrub (unidentified, possibly Pleiocarpidia sp.) that typically grows rooted in rocks in streams or river beds. It is said that mumban cannot be uprooted, even by floods and strong currents.

17 I am grateful to Robert Barrett (personal communication) for reminding me of this alternative pun-ujong orientation of the longhouse. Although it is not characteristic of the upper Paku, it appears to be common in other river regions.

18 Uchibori (1978:63) writes that, following on from the notion that the ujong is polluting, corpses are carried out from the ujong end (downriver) of the longhouse. This is true of a few houses in the Paku, but not of all. Thus, in Kerangan Pinggai the centralizing notion of pun takes priority. As a result, corpses may be removed from both the upriver and downriver ends. The overriding rule is that they not be carried 'in front of' (across) the central tiang pemun. Here both the upriver and downriver ends of the longhouse are ujong and so, in this sense, equally 'polluting'.

19 Tumboh refers to growth in the specific sense of plant growth. Thus plants, as a general category of living things (utai idup), are called utai tumboh, literally 'growing things'. Tumboh is distinguished from mesai, as applied to animals and human beings as well as to plants, meaning to grow in the sense of 'to grow larger'. Figuratively, tumboh also means to begin, form or organize.

20 Padam, to go out, be extinguished. Figuratively, to die or death.

21 Thus, for example, during manggol when new farms are cleared, first offerings are made at sunrise facing eastward. Similarly, prior to harvest, rice stalks are bound together near the centre of the family's farm to form a small shrine (padi tanchang). This shrine serves both to immobilize the aggregate souls of the rice (semengat padi) and to represent the ripened grain as a maiden (dara). In constructing it, and while invoking the padi souls, the performer similarly faces eastward (Sather 1977b:160-161). Finally, at the conclusion of the harvest rites, before returning home, the performer casts a handful of rice panicles to the west at the boundary of the field for the spirits of diminution and predation (antu rua and antu rangka) (Sather 1977b:163-164).

22 Also pendai'. From the root $a i^{\prime}$, water.

23 Each Iban longhouse has two names. In addition to a topographic name, a house is also known by the name of its current headman. Thus, Kerangan Pinggai is also known as Rumah Renang, after its tuai rumah Renang anak Bryon. Kerangan Pinggai refers to a stretch of pebbly river-bed or shingle (kerangan) which marks the location of its penai'. Many of the pebbles making up this shingle are the size and shape of small plates (pinggai), hence the name.

24 From the root makai, 'to eat'.

25 These relations are complicated by migration. The Paku Iban have close ties with their neighbours in the Rimbas, Krian and Julau river regions, these rivers having been pioneered largely by Paku settlers. Houses, for example, in the far upper Paku form sapemakai relations with nearby houses in the upper Rimbas. In addition, the Saribas region was originally pioneered by migrations from the Skrang and in pre-Brooke and early Brooke times the Saribas and Skrang Iban formed a military confederation, mainly against the Balau and Sebuyau Iban, but also for more general coastal raiding (Pringle 1970:46-48). But here the power of rivers to define social boundaries was clearly apparent, overriding even ethnic and religious ties. Thus the Iban in each river region formed warring alliances with the local Malays living downriver, so that the Iban and Malay of one river tended historically to fight against the Iban and Malay of other rivers.

26 Again, reflecting the dichotomous nature of Iban perceptions, the Batang Mandai also exists as a 'real' river in the visible world, in this case a tributary of the Kapuas in Kalimantan Barat. Similarly, Mount Rabong, mentioned later in connection with shamanism, also exists as a natural landmark in the visible world. Located between the headwaters of the Mandai and Kalis rivers, on the true left bank of the Ketungau, its summit can be seen from many parts of Sarawak, including much of the Saribas (Sather 1993). 
27 The dinding ukoi, meant to keep family dogs (ukoi) from entering the apartment.

28 The upper bilik (bilik atas) contains the family's most valued possessions, including its tajau or heirloom jars, while the lower bilik (bilik baroh) forms the principal sleeping and living area.

29 While the Iban speak of these different cross-sectional zones of the longhouse interior as 'upper' and 'lower', the house floor is actually level except for the elevated panggau. Note that for the Gerai Dayaks, described in this collection by Christine Helliwell, the house floor is actually stepped, in a series of higher and lower sections, so that its physical layout is essentially the same as the Iban conceptual plan.

30 From here they could quickly rally to the defence of the community if it were attacked.

31 The east-west orientation of a house is much more variable than the upriver-downriver orientation. Relatively level sites, sufficiently long to accommodate a longhouse, are scarce. Variation from the ideal orientation is sanctioned during the process of selecting a site by bird divination (beburong), which is believed to give direct divine affirmation of a site's auspiciousness whether it is ideally oriented or not (see Sather 1980:xxxi-xliv).

32 Today most women in the Paku omit bekindu' or observe only a few days of heating.

33 In ritual language, 'this world' (dunya tu) is paired with the sky and is most often described in prayer and invocatory chant as 'under the sky' (baroh langit) or 'covered by the sky' (bap langit).

34 Today gourds are no longer used and water is generally carried from the river in plastic pails.

35 These hearths are ordinarily placed on the ruai beneath the trophy heads which are suspended above them (for warmth) on special ring-frames. Thus the longhouse has two sets of hearths: the family dapur and the external bedilang. The latter are placed at the thresholds (antara) between adjoining family sections of the ruai. Instead of earth, the bedilang are made of stone and, like the dapur, are of major ritual importance. The position of the bedilang in warming the trophy heads (antu pala) is analogous to that of the dapur in warming the rice, the one located on the communal gallery, positioned between family sections of the ruai, the other inside the family apartment beneath its rice storage-bins and between adjacent biliks.

36 The head of the body inside the sapat is towards the east or panggau.

37 Some bards deny this, pointing out that the body is already 'hot', and claim that the fire is instead a source of light that guides the dead on its journey to the cemetery.

38 In the poem of lamentation, the role of the entry ladder in preserving the souls of the living is stressed. Thus the spirit of the ladder is made to account for its inattentiveness in allowing the deceased to die, that is, for permitting his/her soul to leave the longhouse and journey to the Otherworld. Various other parts of the longhouse are not only attributed spirit form, but in this manifestation are similarly thought to safeguard the souls of the living members of the community.

39 An important motif of both shamanic rituals and weaving.

40 As we shall see in a moment, limban also refers to lymphatic fluid associated with bodily decomposition.

41 A passage also, note, from west (death) to east (life).

42 Not all Iban locate the ayu there, although this is, in the Paku, the most common shamanic view. Some Iban, in fact, identify the plant image with the hearthframe. This view is consistent with a commonly held notion that the longhouse not only represents the unseen cosmos, but, in actuality, is this cosmos, including the Otherworld of the dead. Thus, some Iban say that the souls of the dead never really leave the longhouse, but are present, living in an inverted world, most often thought to be located beneath the longhouse floor. Offerings to the dead are regularly dropped through the floor slates, usually under the tempuan. Here also, beneath the tempuan, the 'severed flowers' and the rugan altars are thrown in rites which mark the separation of the living and the dead. This view, equating the longhouse and the Otherworld is, of course, consistent with the reversed nature of the soul's journey and the shaman's representation of this journey in his pelian. For another context in which the longhouse interior is perceived as an unseen cosmos see Sather (1978:319-326).

43 Again, the pieces of the sungkup can be carried into the longhouse and assembled on the veranda only after a sacrifice has been made at the foot of the entry ladder and the tiang pemun lustrated with blood, together with the ramu of the Gawai elder. These lustrations (genselan), again, preserve the house from 'heat'.

44 A house must be in good repair to withstand the press of visitors. During one Gawai Antu I attended at Ulu Bayor, Rimbas, the number of guests was so great that, by the end of three nights, the pillars of the house had sunk more than a foot into the earth under their weight. 
45 Today, in modern Gawai Antu they may carry a banner bearing the name of the longhouse they represent.

46 Traditionally the night following the Gawai Antu (malam ngayap maia gawai) was one of licensed courtship, in which married men and women temporarily resumed bachelor and maiden status and were free to engage in courting in honor of the still lingering spirit-heroes and heroines (Sather 1977a:xiii-xiv).

47 It is significant to note that the way in which the longhouse may appear to the unseen spirits and souls may also vary, in a parallel manner, just as the house may assume different 'spiritual' forms in the seen world. Thus, for example, if the ensing, or common kingfisher, flies into the longhouse and down the tempuan passageway past the doors of its biliks, it is regarded as a disastrous omen called burong rajang ruas. It signifies that the longhouse now appears to the spirits as a ruas, a bamboo cooking tube in which meat and other food is stewed. As an omen, it indicates that the longhouse will catch on fire and some of its members burn to death. Until it can be neutralized, and the 'spiritual' appearance of the structure repaired, all families must temporarily evacuate the house (bubus rumah). Ideally, in an inverted way, the longhouse of the living should be invisible to the spirits, just as their lairs are ordinarily invisible to human beings.

48 Helliwell argues persuasively in this collection, and at greater length elsewhere (1990) against a view of the longhouse as composed of highly independent 'household' units, its social life shaped, in an ontologically-prior sense, by the physical division of the house into walled apartments. Although developed in different terms, this argument and the one I pursued here are, I think, mutually supportive. 



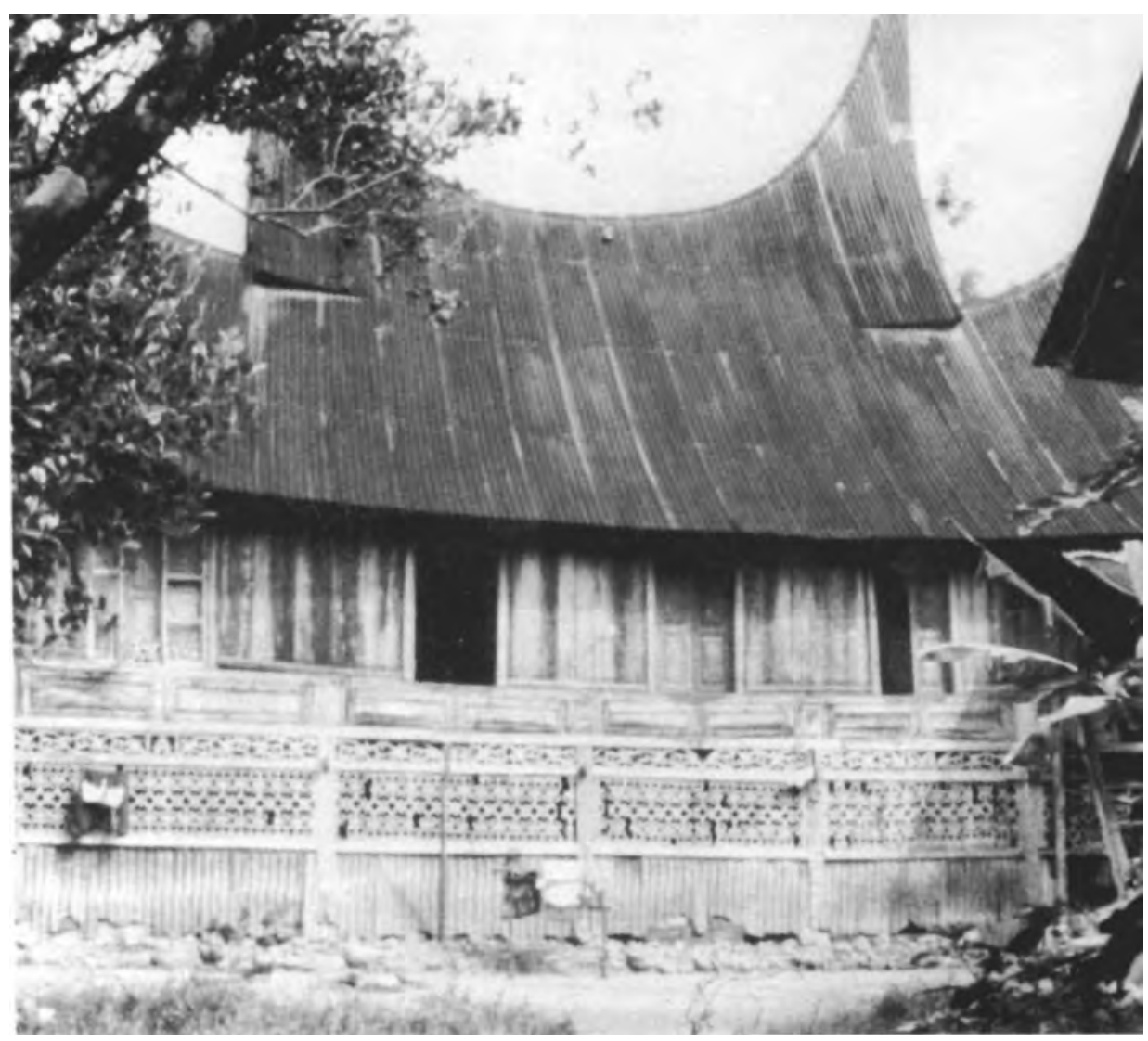

A thirty-post traditional Minangkabau house in Nagari Koto nan Gadang, Lima Puluh Kota 